\title{
Relationships between chemical composition, antioxidant activity and genetic analysis with ISSR markers in flower buds of caper plants (Capparis spinosa $\mathrm{L}$.) of two subspecies spinosa and rupestris of Spanish cultivars
}

\author{
Mar Grimalt • Santiago García-Martínez • Pedro Carbonell • Francisca Hernández • \\ Pilar Legua $\cdot$ María S. Almansa • Asunción Amorós 10
}

Received: 17 June 2021 / Accepted: 22 November 2021/Published online: 3 December 2021

(C) The Author(s) 2021

\begin{abstract}
Genetic diversity and variability between populations is essential for the long-term survival of plant species as well as their adaptation to different habitats. The Capparis spinosa L. has two subspecies in Spain, spinosa with stipules thorny and rupestris without them. In Spain, the subspecies used for its cultivation is spinosa, which is difficult to manipulate due to its stipules thorny. The capers, unripe fruits and tender shoots are used as food. The caper plant is a rich source of phenolic compounds, due to that many flavonoids have been found in different parts of caper plant and in high quantities, which indicates that it is a good source of functional compounds both as food and for nutraceutical applications. There are no published works on the differences in biochemical and functional compounds of both subspecies, so in this work 32 varieties have been genetically analyzed to know
\end{abstract}

M. Grimalt · S. García-Martínez •

P. Carbonell · M. S. Almansa · A. Amorós $(\square)$

Research Group 'Agricultural Biodiversity and Plant

Breeding ', Centro de Investigación E Innovación

Agroalimentaria Y Agroambiental (CIAGRO-UMH),

Miguel Hernández University, Ctra. Beniel, Km 3.2,

03312 Orihuela, Alicante, Spain

e-mail: aamoros@umh.es

F. Hernández · P. Legua

Research Group 'Plant Production and Technology',

Centro de Investigación E Innovación Agroalimentaria Y

Agroambiental (CIAGRO-UMH), Miguel Hernández

University, Ctra. Beniel, Km 3.2,

03312 Orihuela, Alicante, Spain their subspecies. Afterwards, various biochemical and functional parameters have been analyzed to find out if they present differences between both subspecies. From the results of the biochemical and functional parameters studied, there are no difference between the spinosa and rupestis subspecies, in all the parameters studied, except chlorophylls. There was more difference between the results of the subspecies spinosa among them, than with the subspecies rupestris. For all this, it can be concluded that the rupestris subspecies that does not present stipules thorniness can be cultivated, instead of the spinosa subspecies that does present them, without losing functional or nutritional characteristics of the caper buds.

Keywords Antioxidant activity · Flavonoids · Flavonols · Phenols · Capparis spinosa · ISSR

\section{Introduction}

Genetic diversity and variability between populations is essential for the long-term survival of plant species (Wang et al. 2016), as well as their adaptation to different habitats. The family Capparaceae consists of 39 genera and 650 species, which are distributed in warm areas around the world. In the genus Capparis, about 250 species are known (Gull et al. 2015), they 
could be native to the tropics and later spread to the Mediterranean basin and Central Asia (Zohary 1960). The Capparis spinosa L. is a common perennial winter-deciduous shrub with a summer cycle, and it has a creeping growth. It grows in North Africa, Europe, West Asia, Afghanistan and Australia (Inocencio et al. 2006; Fici 2014; Grimalt et al. 2019). The caper plant is largely cultivated in the Mediterranean basin. In Spain, the most valuable parts of Capparis spinosa used as food are the fresh aerial parts, especially the flower buds (capers), unripe fruits and young shoots. These are pickled or kept in brine and used as an appetizer or as a complement to meat, salads, pasta, and other foods (Argentieri et al. 2012; Grimalt et al. 2019). These plants have been used traditionally to prevent a high number of diseases such as diabetes, hepatitis, obesity and kidney problems (Anwar et al. 2016). In recent years, interest in consuming healthy foods has increased (Wu et al. 2004). The caper plant is a rich source of phenolic compounds, due to that many flavonoids have been found in different parts of capers and in high quantities, which indicates that it is a good source of functional compounds both as food and for nutraceutical applications (Grimalt et al. 2018, 2019; Wodyło et al. 2019).

On the other hand, the caper is a xerophytic shrub with a remarkable adaptability to harsh environments. Mediterranean countries are in a region of the world threatened by global warming and $C$. spinosa is a promising crop for arid or semi-arid regions within the climate change context, since the caper plant is highly tolerant to drought and heat stress (Grimalt et al. 2018).

C. spinosa present two different subspecies in wild populations and cultivated forms, $C$. spinos $\mathrm{L}$. subsp. spinosa and C. spinosa L. subsp. rupestris (Sibth. \& Sm.) Nyman) in Spain (Mateo and Crespo 1995) and in Italy (Gristina et al. 2014). The subsp. spinosa is characterized, in the Mediterranean Region, for having branches spreading or erect, multiramified; stipules conspicuous and thorny, mostly recurved, decurrent at the base. While, the subsp. rupestris is characterized, in the Mediterranean Region, for having branches pendulous, unramified or few-ramified; stipules mostly setaceous or caducous, when persisting straight or slightly recurved, not decurrent at the base (Fici et al. 2014). Intermediate phenotypes also appear which increases the genetic diversity of this species (Gristina et al. 2014). From an agricultural point of view, the cultivation and collection of edible parts of this plant is greatly hampered by these stipules thorny. For this reason, it would be very successful to be able to cultivate the subsp. rupestris, which does not show stipules thorny, if this subsp. had a high content of compounds, antioxidant activity and nutritional power with respect to subsp. spinosa, which does present stipules thorny, and that is the subsp. more cultivated.

Undersanding the level of genetic diversity and the genetic structure of this species, we wanted to do genetic analysis of the collected samples to ensure that they belong to each of the subsp. mentioned or if they are intermediate phenotypes. For this analysis, we have used the inter-simple sequence repeats, also known as ISSRs. This DNA analysis technique is a quick and simple technique with low running costs and requiring only small quantities of template DNA. The production of large number of fragments and the reproducibility are other advantages of these markers (Reche et al. 2019), they do not require prior knowledge of the DNA sequence and can be universally applied as dominating markers (Liu et al. 2015). The ISSR markers have already been used successfully on C. spinosa (Saifi et al. 2011; Al-Safadi et al. 2014; Gristina et al. 2014; Liu et al. 2015; Tamboli et al. 2018; Rhimi et al. 2019; Ahmadi et al. 2020). Other DNA analysis techniques such as RAPD (Özbek and Kara 2013) and AFLP (Inocencio et al. 2005; Aichi-Yousfi et al. 2016) have also been used in this species. However, in all cases these techniques have been used to distinguish between several species of the genus Capparis or subspecies of $C$. spinosa with respect to morphological characters of the samples.

The objective of this work is to compare two subspecies of Capparis spinosa, the subspecies spinosa, which has stipules thorny, and the subspecies rupestris, which does not. This study is carried out in order to know if the two subspecies have similar chemical and functional characteristics, since the spinosa subspecies, which has stipules thorny, is the only one cultivated in Spain and its spines make agronomic work very difficult. If the subspecies rupestris, which does not have stipules thorny, had similar functional characteristics, it could be cultivated instead of the subspecies spinosa, which would greatly facilitate agronomic work. To our knowledge, 
this is the first time this study has been done. For this, as specific objectives of the work, we would have to:

(i) to carry out their genetic analysis using ISSR markers of thirty-two Spanish cultivars of Capparis, to ensure the subspecies to which each sample belongs

(ii) to study the functional and nutritional properties of twenty-four Spanish cultivars of Capparis and finally

(iii) to study the relationship between the genetic profile and the functional and nutritional properties, with the purpose of knowing if C. spinosa subsp. rupestris (without stipules thorny) presents a compositional profile differentiate from $C$. spinosa subsp. spinosa (with stipules thorny), to know if subsp rupestris can be cultivated without losing functional and nutritional properties.

\section{Materials and methods}

Experimental conditions and plant material

During the vegetative growth stage of the caper plant (May) forty leaves from four plant (ten per plant) of thirty-two cultivars were hand-harvested in 2018. The cultivars were collected in five locations in the southeast of Spain of which 9 cultivars belong to the subsp. rupestris and 22 to the subsp. spinosa (Table 1). The leaves were immediately taken to the laboratory and frozen at $-80{ }^{\circ} \mathrm{C}$ until they were used for genetic analysis.

During the reproductive growth stage of the caper plant (June and July), forty flower buds (capers) from four caper plant (ten per plant) were hand-harvested. However, there were cultivars that presented pests and did not have the sufficient quality of the capers or were not present, so only 24 cultivars were taken (to study the functional and nutritional properties). Once in the laboratory, forty flower buds of each cultivar in the stage of development called surfines (diameter between $7-8 \mathrm{~mm}$ ) were selected; since they are the stage most used for culinary purposes. Then, the flower buds were freeze-dried using a freeze dryer (Telstar Technologies LyoQuest-55) for $24 \mathrm{~h}$ under reduced pressure, 0.220 mbar. The temperature in the drying chamber was $-25^{\circ} \mathrm{C}$, while the heating plate reached $15{ }^{\circ} \mathrm{C}$. After drying, the samples were stored vacuum-packed in a freezer at $-80{ }^{\circ} \mathrm{C}$ until analysis.

Genetic study

\section{DNA extraction}

Genomic DNA was extracted from young leaves, following the CTAB method with slight modifications (Doyle and Doyle 1990). The extracted DNA was dissolved in water Milli-Q and the final concentration was adjusted to $15 \mathrm{ng} \mu \mathrm{L}^{-1}$, using a Nanodrop spectrophotometer (ThermoFisher Scientific, Waltham, USA).

Table 1 Capparis cultivars and site of collection

\begin{tabular}{|c|c|c|c|c|}
\hline Population & Cultivars & Subspecies ${ }^{\mathrm{a}}$ & $\begin{array}{l}\text { Site of collection (town, } \\
\text { province, country) }\end{array}$ & $\begin{array}{l}\text { Latitude, longitude, } \\
\text { altitude }(\mathrm{m})\end{array}$ \\
\hline EPSO & $\begin{array}{l}\text { TE1, TE2, TE3, TE4, TE5, TE6, TE7, } \\
\text { TE8, TE9,TE10 }\end{array}$ & rupestris & Orihuela, Alicante, Spain & $38^{\circ} 5^{\prime} \mathrm{N}, 0^{\circ} 56^{\prime} \mathrm{W}, 24$ \\
\hline Serón & TS1, TS2, TS3, TS4, TS5, TS6, TS7,TS8 & spinosa & Serón, Almería, Spain & $37^{\circ} 21^{\prime} \mathrm{N}, 2^{\circ} 32^{\prime} \mathrm{W}, 822$ \\
\hline Águilas & TA1, TA2, TA3, TA4, TA5,TA6, TA7 & spinosa & Águilas, Murcia, Spain & $37^{\circ} 24^{\prime} \mathrm{N}, 1^{\circ} 34^{\prime} \mathrm{W}, 21$ \\
\hline $\begin{array}{l}\text { La } \\
\text { Alberca }\end{array}$ & $\begin{array}{l}\text { TALB1, TALB2, TALB3, TALB4, } \\
\text { TALB5 }\end{array}$ & spinosa & La Alberca, Murcia, Spain & $37^{\circ} 56^{\prime} \mathrm{N}, 1^{\circ} 07^{\prime} \mathrm{W}, 88$ \\
\hline $\begin{array}{l}\mathrm{La} \\
\text { Alcayna }\end{array}$ & TALCY1, TALCY2 & spinosa & La Alcayna, Murcia, Spain & $38^{\circ} 05^{\prime} \mathrm{N}, 109^{\prime} \mathrm{W}, 212$ \\
\hline
\end{tabular}

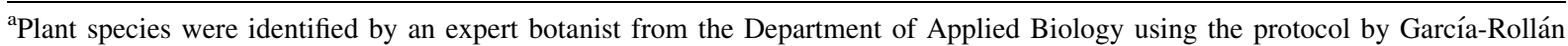
(1981) 
PCR optimization and ISSR selection

We used 6 markers of the UBC primer set \#9 of the University of British Columbia Biotechnology Laboratory (Vancouver, Canada), and 12 markers from the work of Al-Safadi et al. (2014) (Table 2). These markers were the more polymorphic in previous studies (Al-Safadi et al. 2014). Annealing temperature was optimised by running a gradient PCR between 45 and $60{ }^{\circ} \mathrm{C}$. Annealing temperature of $53{ }^{\circ} \mathrm{C}$ obtained the best results. Amplification with each arbitrary primer was repeated twice and only those primers that produced reproducible and consistent bands were only selected for data generation.

\section{PCR amplifications}

Reactions were carried out in $25-\mu \mathrm{L}$ volume containing $30 \mathrm{ng}$ template DNA, $0.5 \mathrm{U}$ TaqDNA polymerase, $10 \mathrm{mM}$ dNTP, $10 \mu \mathrm{M}$ primer in $1 \times$ reaction buffer that contained $10 \mathrm{mM}$ Tris- $\mathrm{HCl}(\mathrm{pH} 8.3), 50 \mathrm{mM} \mathrm{KCl}$ and $2.5 \mathrm{mM} \mathrm{MgCl}_{2}$. The temperature profile used was: a denaturation for $2 \mathrm{~min}$ at $94{ }^{\circ} \mathrm{C}$, then 35 cycles consisting each of a denaturation step for $30 \mathrm{~s}$ at $94^{\circ} \mathrm{C}$;

Table 2 ISSR markers and primer sequence

\begin{tabular}{ll}
\hline Marker & Primer sequence \\
\hline UBC807 & AGAGAGAGAGAGAGAGT \\
UBC814 & CTCTCTCTCTCTCTCTA \\
UBC817 & CACACACACACACACAA \\
UBC820 & GTGTGTGTGTGTGTGTC \\
UBC825 & ACACACACACACACACT \\
UBC829 & TGTGTGTGTGTGTGTGC \\
ISSR1 & CACCACCACCACCACACCACT \\
ISSR2 & GAGAGAGAGAGAGAGAGAC \\
ISSR7 & CACACACACACACACACACAG \\
ISSR8 & CTCTCTCTCTCTCTCTCTG \\
ISSR10 & TCCTCCTCCTCCTCC \\
ISSR13 & AGAGAGAGAGAGAGAGG \\
ISSR14 & GAGAGAGAGAGAGAGAT \\
ISSR15 & GAGAGAGAGAGAGAGAC \\
ISSR16 & GAGAGAGAGAGAGAGAA \\
ISSR19 & CTCTCTCTCTCTCTCTT \\
ISSR22 & GTGTGTGTGGTGTGTA \\
ISSR43 & ACACACACACACACACCTA \\
\hline &
\end{tabular}

an annealing step for $30 \mathrm{~s}$ at $53{ }^{\circ} \mathrm{C}$; an extension step for $1 \mathrm{~min}$ at $72{ }^{\circ} \mathrm{C}$ and the final extension for $5 \mathrm{~min}$ at $72{ }^{\circ} \mathrm{C}$, using a Eppendorf Mastercycler Gradient (Hamburg, Germany).

\section{Electrophoresis conditions}

Amplified products were loaded on $1.5 \%$ agarose gel and separated in $1 \times$ TAE buffer at $100 \mathrm{~V}$. The gels were visualized under UV after staining with ethidium bromide and documented using a gel documentation and image analysis system (Vilber Lourmat, Collégien, France).

\section{Data analysis}

The banding patterns were scored as present (1) or absent (0). Only clear and repeatable fragments were considered in the genetic analysis. Band size determination was carried out using the molecular weight marker GeneRuler100 bp Plus DNA Ladder (ThermoFisher Scientific, Waltham, USA).

Three indexes were calculated: MR (Multiplex Ratio), PIC and RP (Resolving Power). The MR is defined as the number of polymorphic loci found in a reaction (Powell et al. 1996). For dominant (presence/ absence) markers the PIC is defined as $1-\mathrm{Faa}^{2}-\mathrm{Fan}^{2}$, where $\mathrm{Faa}^{2}$ is the frequency of the amplified allele and $\mathrm{Fan}^{2}$ is the frequency of the non-amplified allele. The $\mathrm{RP}$ is defined as $\Sigma I_{b}$, being $\mathrm{I}_{\mathrm{b}}=1-(2|0.5-p|)$, where $p$ is the frequency of the genotypes that contain the band. It represents the ability of a marker to discriminate against the different studied accessions.

Phylogenetic relationships among accessions were estimated from the molecular characterization data, using the package NTSYSpc 2.0 (Adams et al., 1998). Dendrogram was constructed using the Unweighted Pair Group Method with arithmetic averaging (UPGMA) clustering analysis based on the genetic similarity coefficient matrices (Nei and Li 1979). Statistical stability of the branches in the cluster was estimated by bootstrap analysis with 1000 replicates, using the Winboot software program (Yap and Nelson 1996). Population structure was estimated using a model based Bayesian procedure implemented in the software Structure v. 2.3.4 (Pritchard et al. 2000). An admixture model with correlated allele frequencies without prior population information was used. The most informative number of subpopulations was 
identified using the $\mathrm{K}$ method (Evanno et al. 2005) with the aid of Structure Harvester (Earl and Vonholdt 2012). The estimated cluster membership coefficient matrices of the 20 runs were permuted so that all replicates have the closest match possible and then averaged across replicates, using the Greedy algorithm of the software CLUMMP (Jakobsson and Rosenberg 2007). To validate the predefined or the estimated population structure, we calculated pairwise Fst and Nei's standard genetic distance between populations (Nei and Li 1979). The reference distribution for $P$ value calculation of the Fst analysis was calculated using 10,000 permutations. These analyses were performed with the Genalex 6.5 software (Peakall and Smouse 2012).

Biochemical, nutritional and functional parameters

In the capers the following parameters were measured in triplicate:

Chlorophylls $a$ and $b$ were extracted for each sample using $85 \%$ acetone according to Official Method AOAC (1990). The absorbance was read at $664 \mathrm{~nm}$, using Helios Gamma spectrophotometer (model, UVG 1002E; Helios, Cambridge, UK). The results were expressed in $\mathrm{mg} 100 \mathrm{~g}^{-1}$ dry weight (dw).

Total carotenoids were extracted according to Valero et al. (2011), with acetone and diethyl ether to promote phase separation. The lipophilic phase was used to estimate the total carotenoid content and the absorbance was measured at $450 \mathrm{~nm}$ using the same Helios Gamma spectrophotometer named above. The results were expressed as $\mathrm{mg}$ of carotenoids $100 \mathrm{~g}^{-1}$ $\mathrm{dw}$.

To determine the protein content, the Bradford method (1976) was used, using the Bio-Rad reagent. For the quantification, a standard curve of pure bovine serum albumin (BSA) was used, according to Grimalt et al. (2019). The absorbance was measured at $595 \mathrm{~nm}$ using the same Helios Gamma spectrophotometer named above. The results were expressed as $\mathrm{mg} \mathrm{g}^{-1}$ dw.

To estimate the total flavonoids and flavonols, extracts of methanolic caper buds were used using $80 \%$ methanol and a weight-to-volume ratio of $1 / 50$, stirring for $24 \mathrm{~h}$ (Argentieri et al. 2012). The total phenols were quantified according to Singleton et al. (1999), with slight modifications, using the Folin-
Ciocalteu reagent and the calibration curve was performed with gallic acid. The absorbance was measured at $760 \mathrm{~nm}$ using the same Helios Gamma spectrophotometer named above. The results were expressed as mg GAE $100 \mathrm{~g}^{-1} \mathrm{dw}$.

Total flavonoids were quantified using the method of Chang et al. (2002) with some modifications. The reaction was kept at room temperature for $30 \mathrm{~min}$ and the absorbance was measured at $415 \mathrm{~nm}$, using the same Helios Gamma spectrophotometer named above. Total flavonols were quantified using the Kumaran et al. (2007) method with some modifications, and absorbance was measured at $440 \mathrm{~nm}$. The results of flavonoids and flavonols were expressed as $\mathrm{mg}$ rutin Eq. $100 \mathrm{~g}^{-1} \mathrm{dw}$.

The activity of hydrophilic-total antioxidant activity (H-TAA) and lipophilic antioxidant activity (LTAA) of caper buds were determined in the aqueous and organic phases, respectively. The reaction mixture contained $10 \mathrm{mM}$ ABTS, $1 \mathrm{mM}$ hydrogen peroxide, and $10 \mathrm{mM}$ peroxidase in a total volume of $1 \mathrm{~mL}$ of $50 \mathrm{mM}$ glycine- $\mathrm{HCl}$ buffer ( $\mathrm{pH} 4.5$ ) for H-TAA, or ethyl acetate for L-TAA. The reaction was monitored at $730 \mathrm{~nm}$ until a stable absorbance was obtained using the same spectrophotometer named above. After that, a suitable amount of caper buds extract was added and the observed decrease in absorbance was determined. A calibration curve was performed with Trolox as antioxidant standard for both H-TAA and L-TAA (Arnao et al. 2001). The results were expressed as mg Trolox equivalent $100 \mathrm{~g}^{-1} \mathrm{dw}$.

The determination of the total antioxidant activity made by three methods FRAP, $\mathrm{ABTS}^{+}$and DDPH ${ }^{\bullet}$. The ferric reducing ability of plasma (FRAP) and (2,2'-azino-bis (3-ethylbenzothiazoline-6-sulphonic acid)) $\left(\mathrm{ABTS}^{+}\right)$antioxidant assays were determined following Benzie and Strain (1996) and Re et al. (1999), respectively, using the same Helios Gamma spectrophotometer named above. The radical scavenging activity was evaluated using the $\mathrm{DPPH}^{\bullet}$ radical (2,2-diphenyl-1-picrylhydrazyl) method, as described by Brand-Williams et al. (1995). The results were expressed in $\mathrm{mM}$ Trolox per $100 \mathrm{~g}$ of $\mathrm{dw}$.

\section{Statistical analysis}

For physical, chemical and biochemical parameters, a basic descriptive statistical analysis was followed by one-way analysis of variance test (ANOVA) for mean 
comparisons. Three analyzes have been carried out: grouping the cultivars by subspecies, grouping cultivars by populations and without grouping. The method used to discriminate among the means (multiple range test) was Fisher's LSD (Least Significant Difference) procedure at a $95.0 \%$ confidence level. These analyses were performed using the software package SPSS 18.0 for Windows (SPSS Science, Chicago, USA).

Correlation between the different determined parameters was calculated in $\mathrm{R}$ using the package 'reshape2' v. 1.4.3 (Wickham 2007). A Principal Component Analysis (PCA) was performed to determinate which combination of attributes are contributing to phenotypic diversity in our populations. PCA was conducted in $\mathrm{R}$ using the package 'FactoMineR' v. 1.41 (Lê et al. 2008). Three different samples from each population were used to perform the PCA, and the mean from values of weight and diameter/length parameters was included in each population in the data matrix.

\section{Results and discussion}

Genetic diversity and hierarchical classification

The 32 Capparis cultivars were amplified consistently with 8 of the 18 primers (Table 2 and Fig. 1). The number of products generated per primer was found to range from 5 to 15 of different sizes in the range of $0.23-2.20 \mathrm{~kb}$ (Table 3). The primer ISSR15 exhibited the maximum (15) product whereas primer ISSR10 gave the least (5) number of products. A total of 83 amplified products were produced with an average of 10.37 products per primer, of which $81(97.6 \%)$ were polymorphic and $2(2.4 \%)$ products were monomorphic (Table 3). The percentage of polymorphic bands ranged from $80 \%$ for primer ISSR 10 to $100 \%$ for the other primers. These ISSR primers gave a high PIC value of 0.446 for primer ISSR 16 and low PIC value of 0.305 for primer UBC825, with an average PIC value of 0.356 per primer. An average RP of 5.56 per primer was obtained with the highest RP value of 7.59 for primer ISSR 16, and the lowest value of 2.40 for primer ISSR10 (Table 3). These results are similar with obtained through ISSR by Gristina et al. (2014) in Italy and Al-Safadi et al. (2014) in Syria, lower than those obtained by Tamboli et al. (2018) in India and Rhimi et al. (2019) in Tunisia, while they are clearly superior to those obtained with AFLP by Inocencio et al. (2005) in Spain. All works included several Capparis species and/or subspecies.

The dendrogram obtained by the ISSR data appears in Fig. 2. Nei's similarity coefficient ranged from 0.20 to 0.96 . In the dendrogram, obtained only with 8 ISSR markers, two thirds of the nodes were supported by bootstrap values high than $25 \%$, which indicates the robustness of the result obtained. All cultivars could be distinguished with the ISSR markers used. Intrapopulation variability was obtained in all the populations. Subspecie-specific or unique fragments were detected in all the markers (Tables 2 and 3), as in previous works with ISSR (Al-Safadi et al. 2014; Gristina et al. 2014) and AFLP markers (Inocencio et al. 2005).

In the dendrogram (Fig. 2) the cultivars are grouped in two main clusters. Cluster I contains all the TE cultivars with the TE10 cultivars as the most different. Cluster II contains all the rest cultivars, with a good grouping obtained for the others groups: all TS cultivars, except TS7, all TA cultivars, all TALB cultivars except TALB4, and all TALCY cultivars. The clustering of cultivars by subspecie was also found by Gristina et al. (2014) in Italy, as well as by specie by Al-Safadi et al. (2014) in Syria.

Figure 3 shows the PCA obtained with the ISSR results. The first two main principal components (PC1 and PC2) explained the 58.9 and the $7.1 \%$ of the variability, respectively. The cultivar distribution was very similar to that of the dendrogram, with two large groups, and the TE10 cultivar in an intermediate position. No cultivar TE has stipules thorny except TE10, which does. Due to these stipules thorny and the results obtained with PCA, it can be thought that TE10 is a hybrid between the spinosa and rupestris subspecies.

\section{Genetic structure analysis}

The identification of genetically similar groups of plants was performed using an admixture model-based clustering analysis implemented in the software Structure. The Evanno's test indicated that the most informative number of subpopulations $(\mathrm{K})$ is 2 , suggesting the existence of two major clusters in present Capparis cultivars. The inferred population structure is presented in Fig. 4. The groups defined by the Structure's analysis represent statistically different 


\section{UBC807}

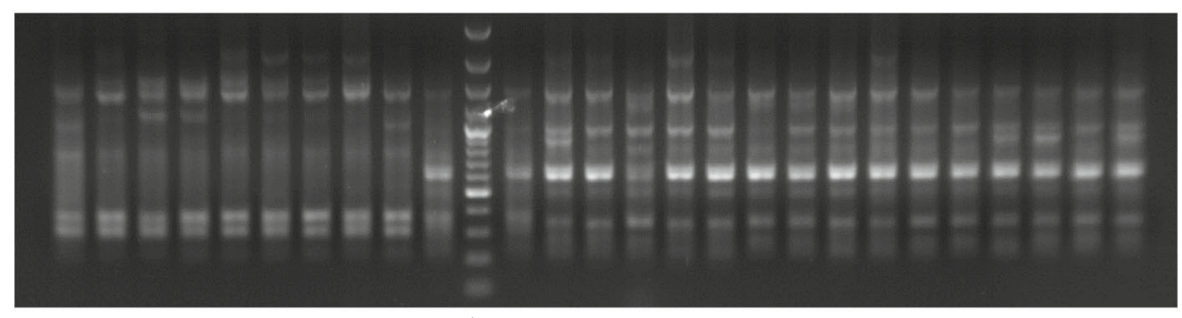

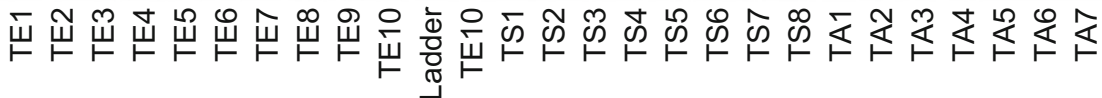

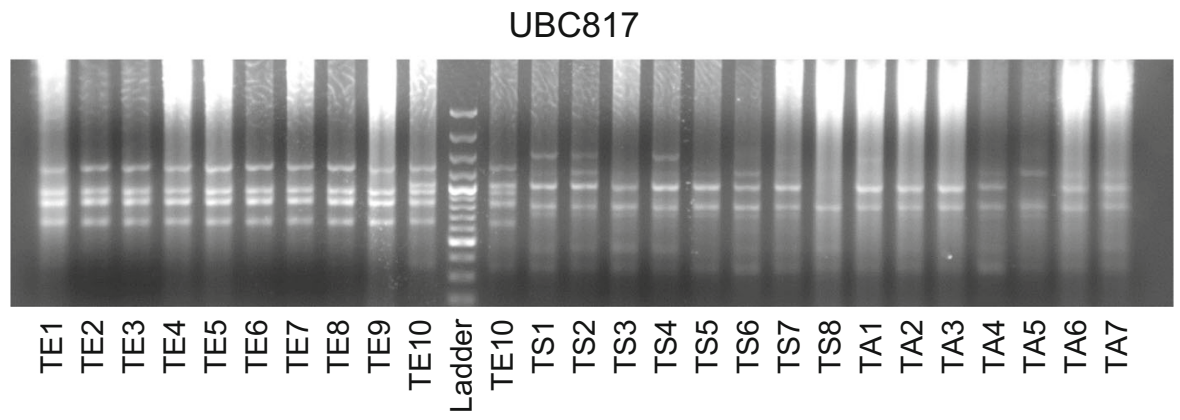

Fig. 1 Banding profiles obtained with the markers UBC807 and UBC817 in part of the studied plants. In each gel, the ladder is GeneRuler100 bp Plus (ThermoFisher)

Table 3 Genetic variation obtained with ISSR markers

\begin{tabular}{lclrlll}
\hline Marker & Number of bands & Size range $(\mathrm{pb})$ & MR & PIC & RP & Unique bands (Number, population) \\
\hline UBC807 & 12 & $320-2200$ & 11 & 0.323 & 6.00 & 3, TE; 4, rest \\
UBC817 & 11 & $350-1650$ & 11 & 0.417 & 6.69 & 4 , TE; 7, rest \\
UBC820 & 7 & $1000-2200$ & 7 & 0.349 & 3.83 & 2 , TE; 1, rest \\
UBC825 & 10 & $460-1750$ & 10 & 0.305 & 4.44 & 1 , TE \\
ISSR10 & 5 & $800-1800$ & 4 & 0.336 & 2.40 & 2 , TE; 2, rest \\
ISSR14 & 12 & $250-1500$ & 12 & 0.364 & 6.57 & 2 , rest \\
ISSR15 & 15 & $230-1750$ & 15 & 0.312 & 6.94 & 4 , TE; 3, rest \\
ISSR16 & 11 & $300-1350$ & 11 & 0.446 & 7.59 & 3 , TE; 2, rest \\
Total & 83 & ND & 81 & ND & ND & 18, TE; 21 rest \\
Average & 10.37 & ND & 10.12 & 0.356 & 5.56 & \\
\hline
\end{tabular}

$M R$ multiplex ratio, $R P$ resolving power, $P I C$ polymorphic information content, $N D$ not determined

subpopulations, as indicated by the evaluation of genetic differentiation. All the cultivars formed two subpopulations: subpopulation 1 consisting of all the TE cultivars (C. spinosa subsp. rupestris) and subpopulation 2 containing the rest of the cultivars of $C$. spinosa subsp. spinosa (TS, TA, TALB and TALCY). Bayesian analysis performed in Structure agrees the results obtained with the UPGMA 


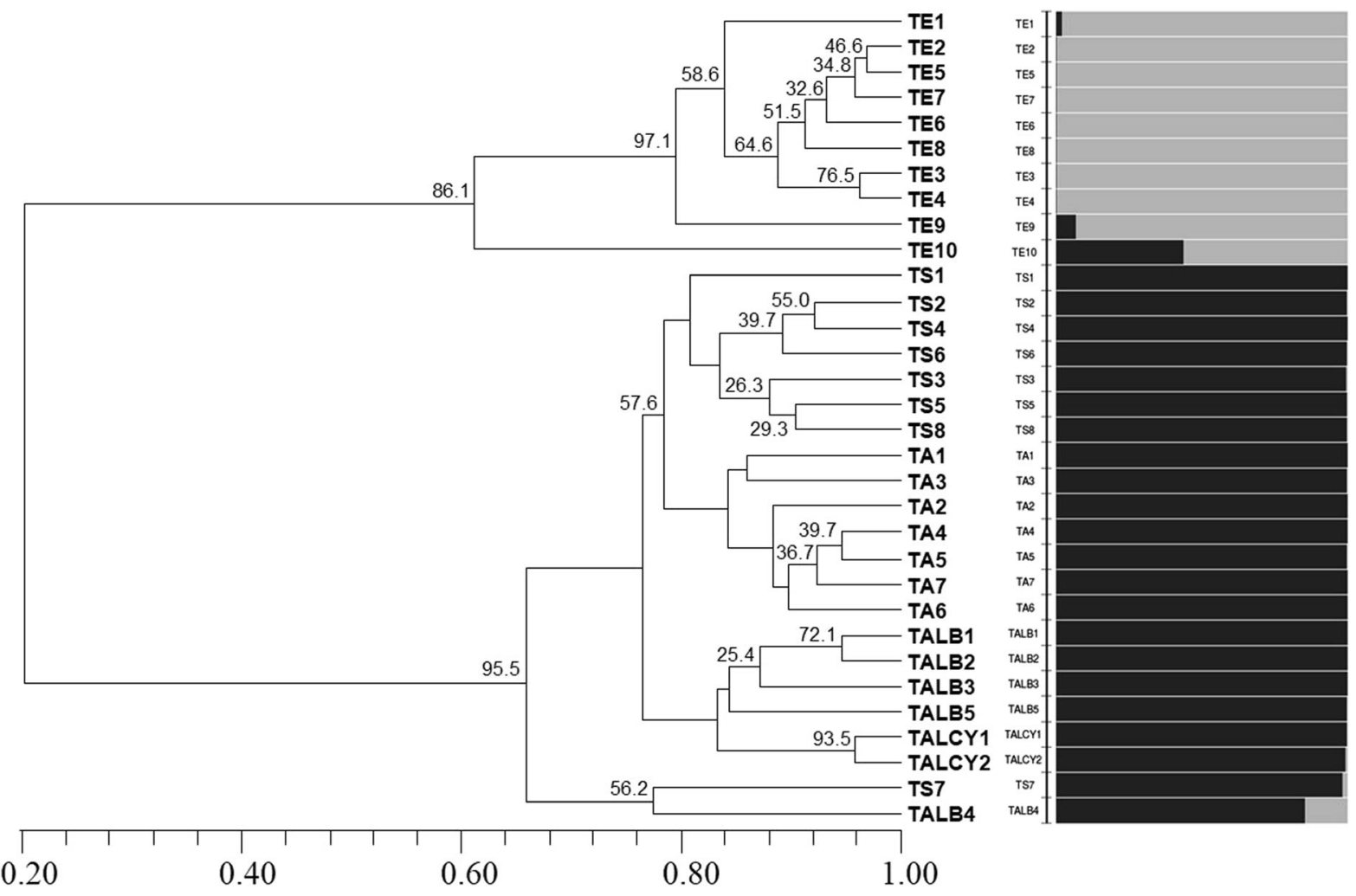

Fig. 2 Genetic relationship among accessions. Left: Dendrogram (UPGMA) of the Capparis plants based on genetic distances calculated with the genetic similarity coefficient matrices. The numbers near nodes represent the percentage of time when the node occurred among 1000 bootstraps (only for nodes with bootstrap values $>25 \%$ are given). Right: estimated population structure of the pea genotypes for $K=2$. Each genotype is represented by a horizontal line, which is partitioned into colored segments that represent the estimated membership fractions in the $\mathrm{K}$ clusters

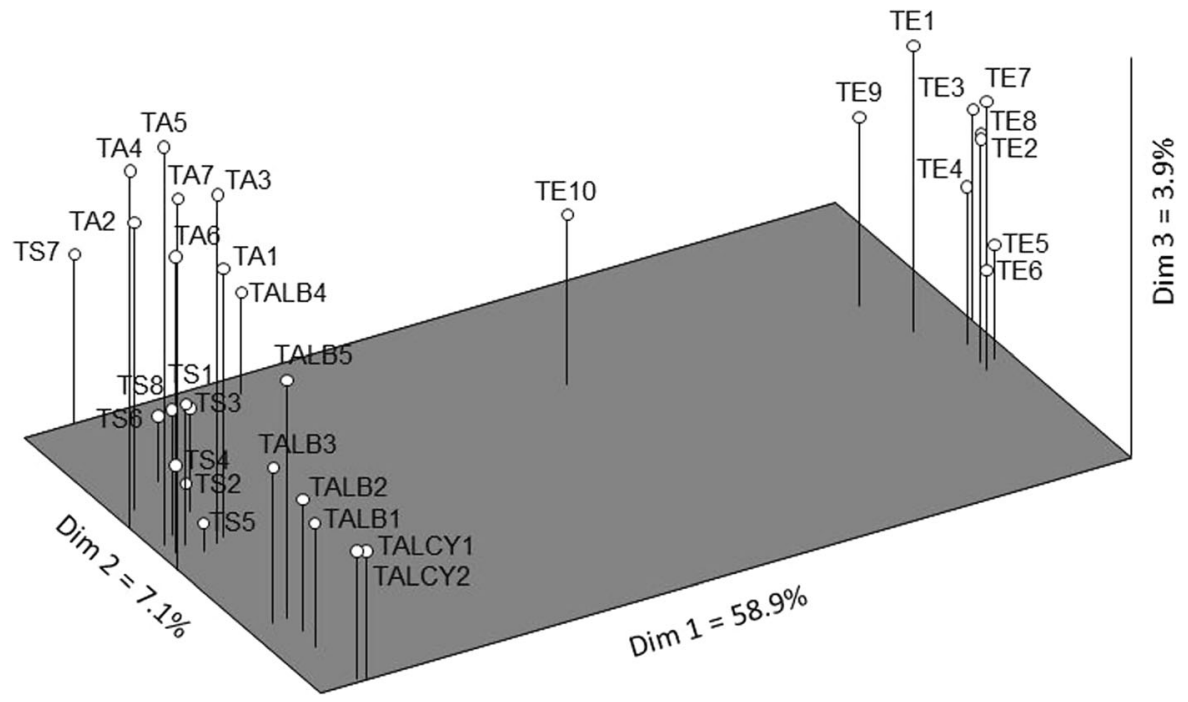

Fig. 3 Principal component analysis (PCA) using the ISSR results 


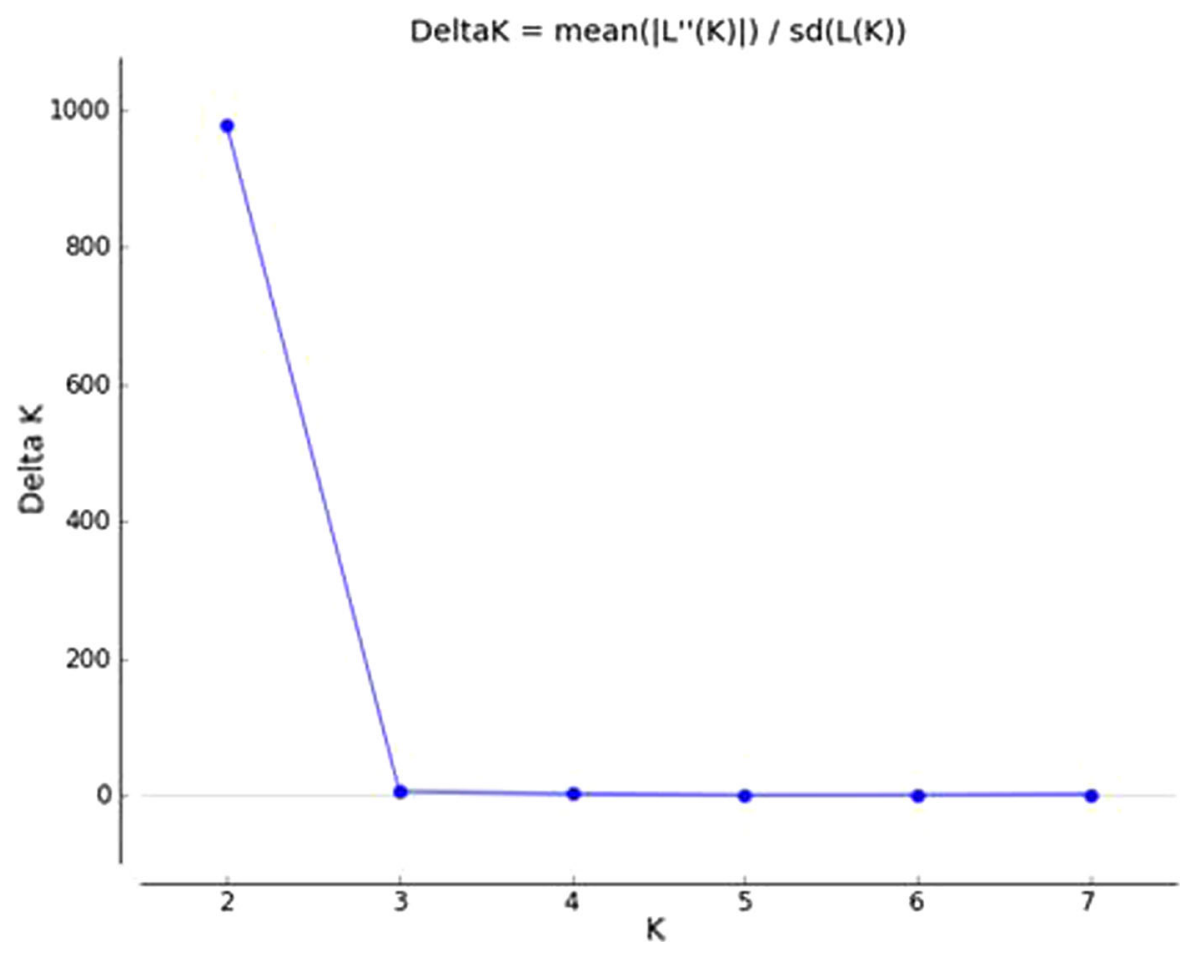

Fig. 4 Estimation of the optimum number of clusters for thepea genotypes according to the Evanno's method. The graph displays the Delta K [mean $(1 \mathrm{~L} 00(\mathrm{~K}) 1 / \mathrm{SD}(\mathrm{L}(\mathrm{K}))]$ for each K value

dendrogram and the PCA, indicating the robustness of the results obtained.

Chlorophyll, carotenoid and protein content in flower buds

The content of chlorophyll $a$, chlorophyll $b$ and total chlorophylls is shown in Table 4. Chlorophyll $a$ presented values from 9.07 to $21.65 \mathrm{mg} 100 \mathrm{~g}^{-1} \mathrm{dw}$ in cultivars'TA5' and 'TE9', respectively. Chlorophyll $b$ content presented its highest value in cultivar 'TE1' with a total of $8.48 \mathrm{mg} 100 \mathrm{~g}^{-1} \mathrm{dw}$, followed by cultivar 'TE4' with a total of $8.44 \mathrm{mg} 100 \mathrm{~g}^{-1} \mathrm{dw}$, being cultivar 'TALCY2' the one with the lowest value, with a total of $4.25 \mathrm{mg} 100 \mathrm{~g}^{-1} \mathrm{dw}$. Regarding the total chlorophylls, the values oscillated from 14.09 to $29.44 \mathrm{mg} 100 \mathrm{~g}^{-1} \mathrm{dw}$, in cultivars 'TA5' and 'TE9', respectively. As observed in Fig. 5, there was a positive correlation between chlorophylls $a$, chlorophylls $b$ and total chlorophylls.

The total content of chlorophylls was influenced by the subsp and population (Table 4). Thus, the $C$. spinosa subsp. rupestris showed the highest content of total chlorophylls compared to $C$. spinosa subsp. spinosa. Regarding the populations, the highest mean value was observed for the TE, TS and TALB $\left(>23.3 \mathrm{mg} 100^{-1} \mathrm{dw}\right.$ ) and the lowest for TA and

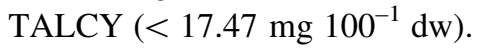

Therefore, spinosa cultivars show a low content of chlorophylls with respect to rupestris, although there are some populations of spinosa that have not presented significant differences with rupestris. Therefore, there are more differences between the spinosa populations than the average between spinosa and rupestris.

The carotenoid content ranged from 20.88 to $59.73 \mathrm{mg} \beta$-carotene $100 \mathrm{~g}^{-1} \mathrm{dw}$, being the cultivar 'TS2' the one with the highest value, followed by cultivar 'TS1' (56.90 mg $\beta$-carotene $100 \mathrm{~g}^{-1} \mathrm{dw}$ ). On the contrary, the cultivar 'TA4' has presented a lower value in carotenoid content. If we relate the results by geographical areas, the TS population presented the highest values of carotenoid content with a mean value of $49.62 \mathrm{mg} \beta$-carotene $100 \mathrm{~g}^{-1} \mathrm{dw}$, followed by 'TALB', 'TALCY' and 'TE' with similar values without significant differences between them, with means values of $45.91,44.92$ and $42.20 \mathrm{mg} \beta$-carotene $100 \mathrm{~g}^{-1} \mathrm{dw}$, respectively. 
Table 4 Photosynthetic pigments $\left(\mathrm{mg} 100^{-1} \mathrm{~g} \mathrm{dw}\right.$ ), carotenoids (mg $\beta$-carotene $100 \mathrm{~g}^{-1} \mathrm{dw}$ ) and proteins content (mg $\left.\mathrm{g}^{-1} \mathrm{dw}\right)$ of flowers buds

\begin{tabular}{|c|c|c|c|c|c|}
\hline & Chlorophyll $a$ & Chlorophyll $b$ & Total chlorophyll & Carotenoids & Protein \\
\hline \multicolumn{6}{|l|}{ Subsp. } \\
\hline rupestris & $18.86 \mathrm{~b}$ & $7.42 \mathrm{~b}$ & $26.27 \mathrm{~b}$ & 42.20 & 10.47 \\
\hline spinosa & $14.79 \mathrm{a}$ & $6.28 \mathrm{a}$ & $21.07 \mathrm{a}$ & 42.50 & 11.96 \\
\hline \multicolumn{6}{|l|}{ Population } \\
\hline $\mathrm{TE}$ & $18.86 \mathrm{~d}$ & $7.42 \mathrm{~b}$ & $26.27 \mathrm{~b}$ & $42.20 \mathrm{ab}$ & $10.47 \mathrm{a}$ \\
\hline $\mathrm{TS}$ & $16.05 \mathrm{bc}$ & $7.27 \mathrm{~b}$ & $23.31 \mathrm{~b}$ & $49.62 \mathrm{~b}$ & $11.79 \mathrm{ab}$ \\
\hline TA & $12.36 \mathrm{a}$ & $5.11 \mathrm{a}$ & $17.47 \mathrm{a}$ & $32.86 \mathrm{a}$ & $11.84 \mathrm{ab}$ \\
\hline TALB & $17.97 \mathrm{~cd}$ & $7.25 \mathrm{~b}$ & $25.21 \mathrm{~b}$ & $45.91 \mathrm{ab}$ & $13.53 \mathrm{~b}$ \\
\hline TALCY & $11.13 \mathrm{a}$ & $4.25 \mathrm{a}$ & $15.38 \mathrm{a}$ & $44.92 \mathrm{ab}$ & $8.63 \mathrm{a}$ \\
\hline \multicolumn{6}{|l|}{ Cultivar } \\
\hline 'TE 1' & $20.90 \pm 1.31^{1 \mathrm{lmn}}$ & $8.48 \pm 1.17^{\mathrm{g}}$ & $29.36 \pm 1.07^{\mathrm{j}}$ & $52.04 \pm 5.89^{\mathrm{ijklm}}$ & $9.84 \pm 0.64^{\mathrm{bc}}$ \\
\hline 'TE 2' & $18.97 \pm 1.76^{\mathrm{ijklmn}}$ & $8.24 \pm 0.59^{\mathrm{g}}$ & $27.21 \pm 2.28^{\mathrm{ij}}$ & $38.40 \pm 2.73^{\text {defg }}$ & $9.82 \pm 0.40^{\mathrm{bcd}}$ \\
\hline 'TE 3' & $19.77 \pm 1.50^{\mathrm{jklmn}}$ & $8.23 \pm 0.62^{\mathrm{g}}$ & $28.00 \pm 1.90^{\mathrm{ij}}$ & $33.45 \pm 1.47^{\text {bcd }}$ & $9.01 \pm 0.06^{\mathrm{abcd}}$ \\
\hline 'TE 4' & $19.08 \pm 0.55^{\mathrm{ijklmn}}$ & $8.44 \pm 0.49^{g}$ & $27.51 \pm 1.00^{\mathrm{ij}}$ & $46.83 \pm 0.57^{\text {ghijk }}$ & $9.47 \pm 0.38^{\mathrm{bc}}$ \\
\hline 'TE 5' & $19.85 \pm 1.20^{\mathrm{ijklmn}}$ & $6.82 \pm 0.63^{\text {defg }}$ & $26.67 \pm 1.03^{\mathrm{ij}}$ & $34.66 \pm 4.91^{\mathrm{defgh}}$ & $9.39 \pm 0.62^{\mathrm{abcd}}$ \\
\hline 'TE 6' & $20.12 \pm 0.99^{\mathrm{klmn}}$ & $6.21 \pm 0.83^{\text {cde }}$ & $26.33 \pm 0.20^{\mathrm{hij}}$ & $49.65 \pm 2.73^{\text {hijkl }}$ & $11.12 \pm 1.09^{\text {bcdef }}$ \\
\hline 'TE 7' & $17.24 \pm 0.96^{\mathrm{fghij}}$ & $7.70 \pm 0.45^{\mathrm{efg}}$ & $24.93 \pm 1.19^{\mathrm{ghi}}$ & $46.49 \pm 2.09^{\mathrm{ghijk}}$ & $11.11 \pm 0.57^{\text {bcdef }}$ \\
\hline 'TE 8 ' & $18.50 \pm 0.25^{\mathrm{hijklm}}$ & $6.63 \pm 0.36^{\mathrm{def}}$ & $25.12 \pm 0.50^{\mathrm{ghi}}$ & $50.34 \pm 1.05^{\mathrm{hijklm}}$ & $11.90 \pm 0.32^{\text {cdef }}$ \\
\hline 'TE 9' & $21.65 \pm 0.97^{\mathrm{n}}$ & $7.80 \pm 0.46^{\mathrm{fg}}$ & $29.44 \pm 1.18^{\mathrm{j}}$ & $45.42 \pm 2.94^{\text {ghij }}$ & $11.62 \pm 1.04^{\text {bcdef }}$ \\
\hline 'TE 10' & $12.48 \pm 0.45^{\mathrm{bcd}}$ & $5.67 \pm 0.51^{\mathrm{abcd}}$ & $18.14 \pm 0.87^{\mathrm{bcd}}$ & $24.72 \pm 0.32^{\mathrm{ab}}$ & $11.46 \pm 0.20^{\mathrm{bcdef}}$ \\
\hline 'TS 1 ' & $14.94 \pm 1.20^{\text {cdef }}$ & $7.80 \pm 0.55^{\mathrm{fg}}$ & $22.73 \pm 0.65^{\mathrm{efg}}$ & $56.90 \pm 3.38^{\mathrm{lm}}$ & $10.47 \pm 0.68^{\text {bcde }}$ \\
\hline 'TS 2' & $18.40 \pm 1.02^{\mathrm{hijkl}}$ & $8.42 \pm 0.36^{\mathrm{g}}$ & $26.81 \pm 0.72^{\mathrm{ij}}$ & $59.73 \pm 1.64^{\mathrm{m}}$ & $13.03 \pm 1.48^{\mathrm{ef}}$ \\
\hline 'TS 3' & $17.65 \pm 0.86^{\mathrm{ghijk}}$ & $7.46 \pm 0.43^{\text {efg }}$ & $25.10 \pm 1.12^{\mathrm{ghi}}$ & $43.55 \pm 1.75^{\text {efghij }}$ & $11.58 \pm 0.47^{\text {bcdef }}$ \\
\hline 'TS 4' & $14.18 \pm 0.09^{\mathrm{cde}}$ & $5.82 \pm 0.43^{\text {bcd }}$ & $19.99 \pm 0.45^{\text {cdef }}$ & $42.93 \pm 4.73^{\text {efghi }}$ & $12.24 \pm 1.54^{\mathrm{def}}$ \\
\hline 'TS 5' & $15.06 \pm 0.44^{\text {bcdefgh }}$ & $6.86 \pm 0.04^{\text {cdefg }}$ & $21.91 \pm 0.41^{\mathrm{efg}}$ & $45.02 \pm 3.67^{\mathrm{ghij}}$ & $11.67 \pm 0.95^{\mathrm{cdef}}$ \\
\hline 'TA 1' & $12.59 \pm 0.77^{\mathrm{bcd}}$ & $4.40 \pm 0.33^{\mathrm{ab}}$ & $16.99 \pm 0.46^{\mathrm{abc}}$ & $27.17 \pm 2.71^{\mathrm{abc}}$ & $9.02 \pm 1.04^{\mathrm{ab}}$ \\
\hline 'TA 2', & $13.30 \pm 0.28^{\mathrm{bcd}}$ & $5.44 \pm 0.26^{\mathrm{abcd}}$ & $18.73 \pm 0.14^{\text {cde }}$ & $32.35 \pm 3.12^{\mathrm{bcd}}$ & $11.29 \pm 1.36^{\text {bcdef }}$ \\
\hline 'TA 3' & $11.69 \pm 0.20^{\mathrm{abc}}$ & $5.79 \pm 0.22^{\mathrm{bcd}}$ & $17.48 \pm 0.35^{\text {bcd }}$ & $47.65 \pm 5.45^{\mathrm{ghijk}}$ & $16.66 \pm 1.26^{\mathrm{g}}$ \\
\hline 'TA 4' & $15.16 \pm 0.40^{\operatorname{defg}}$ & $4.92 \pm 0.32^{\mathrm{abc}}$ & $20.08 \pm 0.54^{\text {cdef }}$ & $20.88 \pm 2.20^{\mathrm{a}}$ & $10.79 \pm 1.55^{\text {bcdef }}$ \\
\hline 'TA 5', & $9.07 \pm 0.21^{\mathrm{a}}$ & $5.02 \pm 0.09^{\mathrm{abc}}$ & $14.09 \pm 0.29^{\mathrm{a}}$ & $36.23 \pm 2.18^{\text {cdef }}$ & $11.44 \pm 0.41^{\text {bcde }}$ \\
\hline 'TALB 1' & $16.58 \pm 0.49^{\text {efghi }}$ & $6.43 \pm 0.46^{\mathrm{cdef}}$ & $23.01 \pm 0.39^{\mathrm{fgh}}$ & $53.96 \pm 1.90^{\mathrm{klm}}$ & $15.71 \pm 0.49^{\mathrm{g}}$ \\
\hline 'TALB 2' & $21.35 \pm 1.53 \mathrm{mn}$ & $7.93 \pm 0.78^{\mathrm{fg}}$ & $29.27 \pm 2.28^{\mathrm{j}}$ & $52.66 \pm 0.28^{\mathrm{jklm}}$ & $14.42 \pm 0.35^{\mathrm{fg}}$ \\
\hline 'TALB 4' & $15.97 \pm 0.21^{\text {defghij }}$ & $7.39 \pm 0.51^{\text {defg }}$ & $23.36 \pm 0.75^{\text {efghi }}$ & $31.11 \pm 1.61^{\mathrm{bcde}}$ & $10.46 \pm 1.80^{\text {bcdef }}$ \\
\hline 'TALCY 2' & $11.13 \pm 2.25^{\mathrm{ab}}$ & $4.25 \pm 0.47^{\mathrm{a}}$ & $15.38 \pm 2.72^{\mathrm{ab}}$ & $44.92 \pm 3.75^{\text {fghijkl }}$ & $8.63 \pm 1.59^{\mathrm{a}}$ \\
\hline
\end{tabular}

Values (means \pm standard error) followed by the same letter, within the same column, were not significantly different according to Fisher's least significant difference (LSD) procedure at 95\% confidence level $(n=30)$. TE: cultivar EPSO; TS: cultivar Serón; TA: cultivar Aguilas; TALB: cultivar La Alberca; TALCY: cultivar La Alcayna

On the other hand, the protein content was not affected by subsp. but population affected it. The 'TALB' population presented the highest values (13.53 mg $100 \mathrm{~g}^{-1} \mathrm{dw}$ ), followed by the 'TS' and
'TA' population that presented mean values of 11.79 and $11.84 \mathrm{mg} 100 \mathrm{~g}^{-1} \mathrm{dw}$, respectively, without significantly differences between them. The lowest mean values were observed for 'TE' and 'ALCY' 


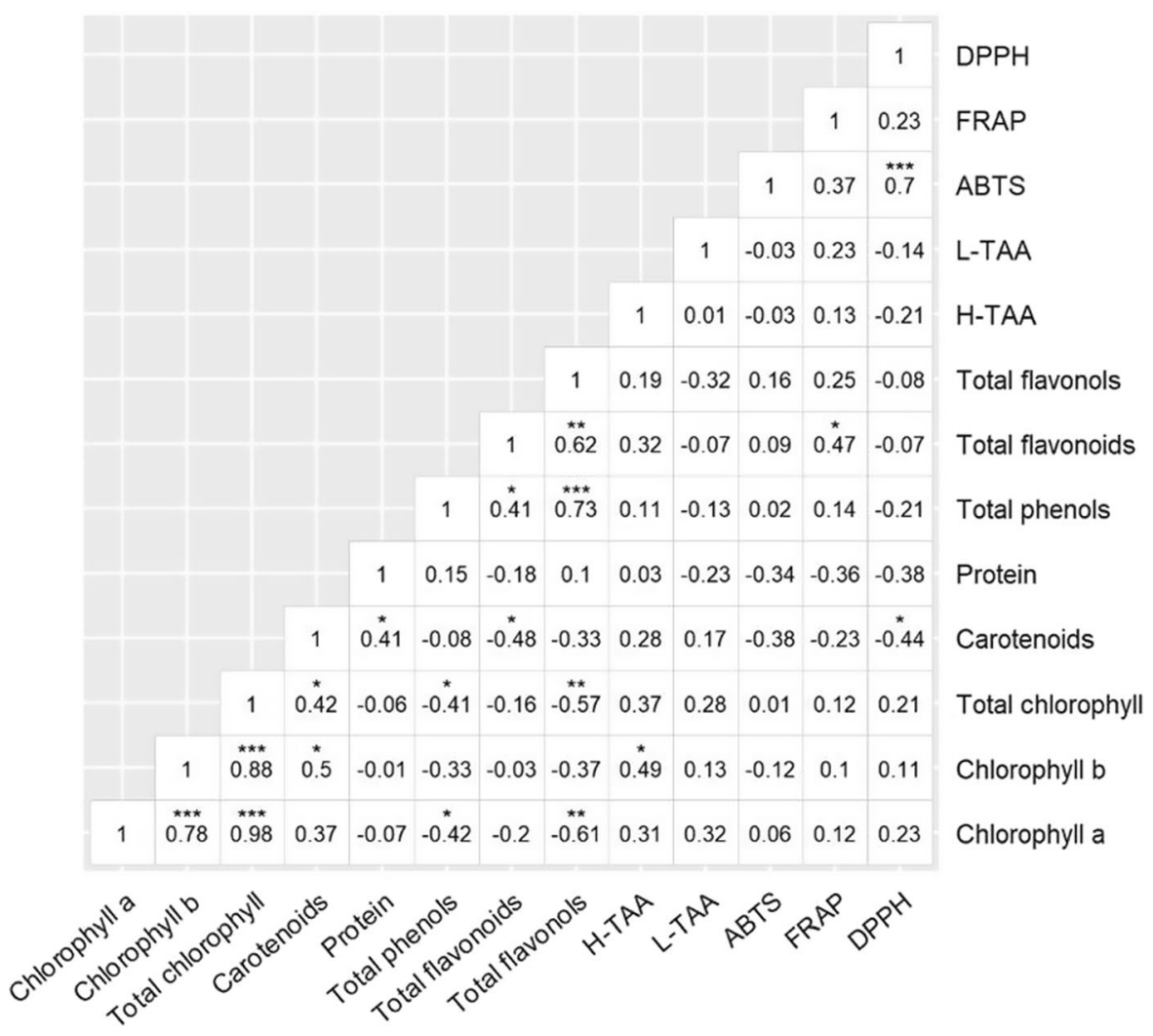

Fig. 5 Pearson coefficient of the correlations between chemical and biochemical parameters. Positive correlations are represented by positive values, and negative correlations by negative values. The significance level of correlations is represented by $*$ $(p$ value $<0.5), * *(p$ value $<0.01)$ and $* * *(p$ value $<0.001)$

There are not many previous studies on the biochemical properties of $C$. spinosa in Spain. These results did not agree those reported by Grimalt et al. (2019), who observed higher content of total chlorophylls and proteins and lower content of carotenoids compared to ours. This may be due to the fact that the collection dates were different and possibly the climatic effects have generated these differences. Ulukapi et al. (2016) obtained a carotenoid content of $21.24 \mathrm{mg} \mathrm{kg}^{-1}$ in capers from Turkey, values lower than those of the present study. Tlili et al. (2009) obtained a carotenoid content in a range between 411.3 and $3452.5 \mu \mathrm{g} \mathrm{g}^{-1} \mathrm{fw}$, so our values are in the same interval. Grimalt et al. (2019), Özcan and Akgül (1998) and Ulukapi et al. (2016) have been obtained higher results in the content of protein that in this study. This is possibly due that they are found in different geographical areas and different cultivars. 
Table 5 Total phenols (mg GAE $100 \mathrm{~g}^{-1} \mathrm{dw}$ ), flavonoids and flavonols (mg rutin Eq. $100 \mathrm{~g}^{-1} \mathrm{dw}$ ) of flowers buds
Values (means \pm standard error) followed by the same letter, within the same column, were not significantly different according to Fisher's least significant difference (LSD) procedure at $95 \%$

confidence level $(n=30)$.

TE: cultivar EPSO; TS: cultivar Serón; TA: cultivar Aguilas; TALB: cultivar La Alberca; TALCY: cultivar La Alcayna

\begin{tabular}{|c|c|c|c|}
\hline & Total phenols & Total flavonoids & Total flavonols \\
\hline \multicolumn{4}{|l|}{ Subsp. } \\
\hline rupestris & $1571.45 \mathrm{a}$ & 2166.70 & $1426.43 \mathrm{a}$ \\
\hline spinosa & $2183.54 \mathrm{~b}$ & 2187.79 & $1810.32 \mathrm{~b}$ \\
\hline \multicolumn{4}{|l|}{ Pupulation } \\
\hline TE & $1571.45 \mathrm{a}$ & $2166.70 \mathrm{ab}$ & $1426.43 \mathrm{a}$ \\
\hline $\mathrm{TS}$ & $2445.69 \mathrm{~b}$ & $2197.61 \mathrm{ab}$ & $1854.39 \mathrm{~b}$ \\
\hline TA & $2440.54 \mathrm{~b}$ & $2305.08 \mathrm{~b}$ & $1993.95 \mathrm{~b}$ \\
\hline TALB & $1547.84 \mathrm{a}$ & $2046.02 \mathrm{a}$ & $1551.37 \mathrm{a}$ \\
\hline TALCY & $1494.86 \mathrm{a}$ & $1977.69 \mathrm{a}$ & $1448.62 \mathrm{a}$ \\
\hline \multicolumn{4}{|l|}{ Cultivar } \\
\hline 'TE 1' & $1694.14 \pm 32.87^{\mathrm{bc}}$ & $2334.27 \pm 55.01^{\mathrm{defgh}}$ & $1353.31 \pm 49.93^{\mathrm{ab}}$ \\
\hline 'TE 2' & $1676.79 \pm 43.12^{\mathrm{bc}}$ & $2404.08 \pm 79.22^{\mathrm{fgh}}$ & $1642.30 \pm 116.25^{\text {bcdefgh }}$ \\
\hline 'TE 3' & $896.25 \pm 49.26^{\mathrm{a}}$ & $2157.95 \pm 156.90^{\text {abcdefgh }}$ & $1428.35 \pm 230.24^{\mathrm{abcd}}$ \\
\hline 'TE 4' & $1396.44 \pm 97.72^{\mathrm{ab}}$ & $2140.19 \pm 65.93^{\text {abcdefgh }}$ & $1410.55 \pm 26.73^{\mathrm{abc}}$ \\
\hline 'TE 5' & $2030.31 \pm 2.17^{\text {cde }}$ & $1954.20 \pm 84.26^{\mathrm{abc}}$ & $1378.24 \pm 50.27^{\mathrm{abc}}$ \\
\hline 'TE 6' & $1679.32 \pm 28.96^{\mathrm{bc}}$ & $2054.93 \pm 75.14^{\text {abcde }}$ & $1363.02 \pm 66.71^{\mathrm{ab}}$ \\
\hline 'TE 7' & $1724.51 \pm 22.59^{\mathrm{bc}}$ & $2043.17 \pm 91.89^{\text {abcde }}$ & $1449.51 \pm 85.33^{\mathrm{abc}}$ \\
\hline 'TE 8' & $1491.06 \pm 129.54^{\mathrm{b}}$ & $2032.83 \pm 166.00^{\mathrm{abcd}}$ & $1299.80 \pm 72.48^{\mathrm{a}}$ \\
\hline 'TE 9' & $1633.26 \pm 59.60^{\mathrm{bc}}$ & $2215.48 \pm 81.54^{\text {bcdefgh }}$ & $1421.08 \pm 54.86^{\mathrm{abcd}}$ \\
\hline 'TE 10' & $1492.40 \pm 162.13^{\mathrm{b}}$ & $2329.86 \pm 195.99^{\mathrm{defgh}}$ & $1518.16 \pm 122.96^{\text {abcde }}$ \\
\hline 'TS 1' & $2899.88 \pm 66.53^{\mathrm{g}}$ & $2274.37 \pm 82.88^{\text {bcdefgh }}$ & $2107.02 \pm 82.02^{\mathrm{jk}}$ \\
\hline 'TS 2' & $1784.84 \pm 289.65^{\mathrm{bcd}}$ & $2063.61 \pm 60.18^{\text {abcdef }}$ & $1669.10 \pm 30.01^{\text {cdefg }}$ \\
\hline 'TS 3' & $2416.73 \pm 249.64^{\text {ef }}$ & $2293.41 \pm 125.07^{\text {cdefgh }}$ & $1897.33 \pm 121.84^{\text {fghij }}$ \\
\hline 'TS 4' & $2432.23 \pm 361.11^{\mathrm{ef}}$ & $2099.84 \pm 21.05^{\text {abcdefg }}$ & $1758.88 \pm 146.34^{\mathrm{defghi}}$ \\
\hline 'TS 5', & $2694.75 \pm 168.28^{\mathrm{fg}}$ & $2256.83 \pm 93.01^{\text {bcdefgh }}$ & $1839.64 \pm 16437^{\text {fghij }}$ \\
\hline 'TA 1 ' & $2771.26 \pm 150.92^{\mathrm{fg}}$ & $2248.99 \pm 155.73^{\text {bcdefgh }}$ & $1869.77 \pm 170.12^{\text {fghij }}$ \\
\hline 'TA 2', & $2772.67 \pm 240.67^{\mathrm{fg}}$ & $2276.86 \pm 8.25^{\text {bcdefgh }}$ & $1930.43 \pm 39.08^{\text {ghijk }}$ \\
\hline 'TA 3' & $2787.94 \pm 244.86^{\mathrm{fg}}$ & $2349.45 \pm 141.45^{\text {efgh }}$ & $1951.59 \pm 80.72^{\mathrm{hijk}}$ \\
\hline 'TA 4', & $2308.72 \pm 43.12^{\mathrm{def}}$ & $2495.46 \pm 153.91^{\mathrm{h}}$ & $2227.77 \pm 225.85^{\mathrm{k}}$ \\
\hline 'TA 5', & $1562.10 \pm 46.65^{\mathrm{bc}}$ & $2154.63 \pm 58.86^{\text {abcdefgh }}$ & $1990.21 \pm 68.06^{\mathrm{ijk}}$ \\
\hline 'TALB 1' & $1506.16 \pm 181.30^{\mathrm{b}}$ & $1849.55 \pm 43.59^{\mathrm{a}}$ & $1425.30 \pm 50.85^{\mathrm{abc}}$ \\
\hline 'TALB 2', & $1473.36 \pm 73.12^{\mathrm{b}}$ & $1995.32 \pm 190.12^{\mathrm{abcd}}$ & $1453.98 \pm 109.27^{\text {abcde }}$ \\
\hline 'TALB 4' & $1664.00 \pm 69.45^{\mathrm{bc}}$ & $2293.18 \pm 158.43^{\text {bcdefgh }}$ & $1774.82 \pm 211.57^{\text {efghi }}$ \\
\hline 'TALCY 2' & $1494.86 \pm 103.08^{\mathrm{bc}}$ & $1977.59 \pm 71.00^{\mathrm{ab}}$ & $1448.62 \pm 57.21^{\mathrm{abc}}$ \\
\hline
\end{tabular}

Total phenols content (TPC), flavonoids and flavonols in the flower buds

Table 5 shows the results of total phenols content (TPC), flavonoids and flavonols analyzed in flower buds. The total phenols content and total flavonols were affected by subsp and population, while the total flavonoids was only affected by population.

Regarding the cultivars, higher value of total phenols content was observed in the cultivar 'TS1' with a total of $2899.88 \mathrm{mg} \mathrm{GAE} 100 \mathrm{~g}^{-1} \mathrm{dw}$, followed by the cultivar 'TA2', being on the contrary the cultivars 'TE3' the one who presented the lowest values (896.25 mg GAE $100 \mathrm{~g}^{-1} \mathrm{dw}$ ). On the other hand, significant differences were detected between populations and also among subsp. Flowers buds of 'TS' and 'TA' populations showed the highest total phenols content $\left(>2.440 \mathrm{mg}\right.$ GAE $\left.100 \mathrm{~g}^{-1} \mathrm{dw}\right)$ in opposition to populations 'TE', 'TALB' and 'TALCY'; while between subsp. the flower buds of 
subsp. spinosa showed the higher total phenols content in comparison with subsp. rupestris. The results obtained showed that the total phenols content was influenced by the genotype and environment conditions.

In reference to the total flavonoid content, this was not affected by the subsp.; however, significant differences were reported for populations and among cultivars. Thus, the maximum values were obtained for the flower buds of 'TA', 'TS' and 'TE' populations (>2160 mg rutin Eq. $100 \mathrm{~g}^{-1} \mathrm{dw}$ ). Regarding among cultivars the total flavonoid content ranged from 1849.55 to $2495.46 \mathrm{mg}$ rutin Eq. $100 \mathrm{~g}^{-1} \mathrm{dw}$ ('TALB1' and 'TA4', respectively). Finally, the total flavonols content, was also significantly affected by subsp., populations and cultivars. Thus, the flower buds with higher value was observed for subsp. spinosa and among populations for 'TS' and 'TA' (> $1854.39 \mathrm{mg}$ rutin Eq. $100 \mathrm{~g}^{-1} \mathrm{dw}$ ); while among cultivars the higher values were observed for cultivar 'TA4' (2227.77 mg GAE $100 \mathrm{~g}^{-1} \mathrm{dw}$ ), while the cultivar 'TE8' presented the lower content compared to the other cultivars.

There is a negative correlation between chlorophylls $a$ and total chlorophylls with the total content of total phenols and flavonols, and this is reflected in the results obtained (Fig. 5). Thus, the cultivar 'TE9' has presented a high content of chlorophylls $a$ and total with respect to the other cultivars, while in the content of total phenols and flavonols it has presented one of the lowest values.

Aliyazicioglu et al. (2013) obtained a total phenol value of $37.01 \mathrm{mg} \mathrm{GAE} 100 \mathrm{~g}^{-1} \mathrm{DW}$, which is much lower than those obtained in this study. In another study carried out in different regions of Tunisian (Tlili et al. 2010), low values were obtained compared to those obtained in the present work, with a total of $2.74 \mathrm{mg} 100 \mathrm{~g}^{-1}$ fw. However, Mansour et al. (2016) obtained higher values in $C$. spinosa than those of the present work, with a total of $427.27 \mathrm{mg} \mathrm{GAE} \mathrm{g}^{-1} \mathrm{dw}$ in total phenols and $57.93 \mathrm{mg} \mathrm{QE} \mathrm{g}^{-1} \mathrm{dw}$ in flavonoids. Tesoriere et al. (2007) obtained $48.75 \mathrm{mg}$ GAE $100 \mathrm{~g}^{-1}$. Maldini et al. (2016) obtained values of total phenols between 98 and $149 \mathrm{mg} 100 \mathrm{~g}^{-1} \mathrm{FW}$, among which flavonoids were the majority with 82-117 mg RE $100 \mathrm{~g}^{-1} \mathrm{FW}$. Inocencio et al. (2000) observed a wide variation in the flavonoid contents of capers from different regions and they proposed that environmental and physiological factors could have important effects. Compared with total phenols of other crops such as mango (208 mg $\left.100 \mathrm{~g}^{-1}\right)$, bilberry (525 mg $100 \mathrm{~g}^{-1}$ ) or raspberry (517 mg $100 \mathrm{~g}^{-1}$ ), the results in Capparis spinosa showed that it is an excellent natural source of these compounds (Tlili et al. 2010).

Total content of antioxidant activity (TAA) in the flower buds

The total antioxidant activity has been quantified by the $\mathrm{ABTS}^{+}$method in the hydro-soluble (H-TAA) and lipidic-soluble (L-TAA) fractions in the caper flower buds of $C$. spinosa (Table 6). Results from TAA (both H-TAA and L-TAA) showed that genotype plays an important role in determining the antioxidant capacity of each cultivar. H-TAA did not show differences between subspecies, although it did between populations, being the cultivar 'TS' the one that presents the highest values, with an average of $1403.36 \mathrm{mg}$ Trolox Eq. $100 \mathrm{~g}^{-1} \mathrm{dw}$, followed by 'TE' cultivars that presented an average of $1036.93 \mathrm{mg}$ Trolox Eq. $100 \mathrm{~g}^{-1} \mathrm{dw}$. 'TA', 'TALB' and 'TALCY' presented the lowest values and without significant differences between them. Regarding cultivars, the H-TAA content showed values in a range between 384.99 and $1883.13 \mathrm{mg}$ Trolox Eq. $100 \mathrm{~g}^{-1} \mathrm{dw}$ in cultivars 'TALB4' and 'TS1', respectively. In the case of the L-TAA content, there were differences between subspecies and population, being the rupestris subspecies and the 'TE' population the ones that presented the highest L-TAA. Regarding the cultivars, 'TE6' presented the highest value with $460.00 \mathrm{mg}$ Trolox Eq. $100 \mathrm{~g}^{-1} \mathrm{dw}$ and the lowest was presented by 'TALB2' with a total of $158.49 \mathrm{mg}$ Trolox Eq. $100 \mathrm{~g}^{-1} \mathrm{dw}$. Although the differences were not significant in the mean of the subsp. rupestris and spinosa for the H-TAA parameter and they have been for the L-TAA parameter, in both cases more differences were found in the contents of both parameters between the populations of spinosa than between the means of spinosa and rupestris.

Antioxidant activity was not significantly different among the subsp. and populations, but yes among cultivars (Table 6). In all cases of TAA, there were more differences between the spinosa populations than between spinosa and rupestris populations. The antioxidant activity by the $\mathrm{ABTS}^{+}$method presented the highest values in the cultivar 'TE5' with a total of 
Table 6 H-TAA and L-TAA and total antioxidant activity by different methods: $\mathrm{ABTS}^{+}$, DPPH ${ }^{\bullet}$ and FRAP (mg Trolox Eq. $100 \mathrm{~g}^{-1} \mathrm{dw}$ ) of flower buds

\begin{tabular}{|c|c|c|c|c|c|}
\hline & H-TAA & L-TAA & $\mathrm{ABTS}^{+}$ & FRAP & $\mathrm{DPPH}$ \\
\hline \multicolumn{6}{|l|}{ Subsp. } \\
\hline rupestris & 1036.93 & $305.85 \mathrm{~b}$ & 547.00 & 1799.91 & 804.46 \\
\hline spinosa & 967.56 & $214.54 \mathrm{a}$ & 550.46 & 1653.09 & 723.12 \\
\hline \multicolumn{6}{|l|}{ Population } \\
\hline TE & $1036.93 \mathrm{ab}$ & $305.81 \mathrm{~b}$ & 547.7 & 1799.91 & 804.46 \\
\hline TS & $1403.36 \mathrm{~b}$ & $215.88 \mathrm{a}$ & 535.92 & 1787.52 & 578.87 \\
\hline TA & $821.18 \mathrm{a}$ & $246.74 \mathrm{ab}$ & 585.28 & 1720.64 & 686.29 \\
\hline TALB & $654.44 \mathrm{a}$ & $168.67 \mathrm{a}$ & 481.81 & 1389.95 & 986.39 \\
\hline TALCY & $459.84 \mathrm{a}$ & $184.46 \mathrm{a}$ & 655.01 & 1432.66 & 838.72 \\
\hline \multicolumn{6}{|l|}{ Cultivar } \\
\hline 'TE 1' & $1126.15 \pm 72.48^{\mathrm{fgh}}$ & $279.11 \pm 33.75^{\mathrm{fg}}$ & $497.07 \pm 37.54^{\text {cdef }}$ & $2191.79 \pm 221.01^{\mathrm{gh}}$ & $462.79 \pm 22.53^{\mathrm{abcd}}$ \\
\hline 'TE 2' & $1223.37 \pm 32.55^{\text {fghij }}$ & $276.41 \pm 83.45^{\mathrm{hi}}$ & $578.92 \pm 20.02^{\mathrm{fg}}$ & $2033.86 \pm 114.38^{\mathrm{fgh}}$ & $582.17 \pm 28.28^{\text {cdefgh }}$ \\
\hline 'TE 3' & $1133.69 \pm 98.56^{\mathrm{efghi}}$ & $279.34 \pm 100.66^{\mathrm{hi}}$ & $661.02 \pm 186.22^{\mathrm{gh}}$ & $1259.21 \pm 64.07^{\mathrm{bc}}$ & $1392.11 \pm 93.36^{\mathrm{lm}}$ \\
\hline 'TE 4' & $1046.38 \pm 107.14^{\mathrm{efgh}}$ & $359.80 \pm 26.30^{\mathrm{hi}}$ & $544.13 \pm 27.03^{\text {ef }}$ & $1733.26 \pm 14.52^{\mathrm{def}}$ & $961.86 \pm 15.77^{\mathrm{jk}}$ \\
\hline 'TE 5' & $562.26 \pm 235.40^{\mathrm{ab}}$ & $264.66 \pm 49.14^{\mathrm{def}}$ & $801.68 \pm 10.26^{\mathrm{k}}$ & $1751.53 \pm 31.79^{\text {bcddef }}$ & $1939.25 \pm 164.69^{\mathrm{n}}$ \\
\hline 'TE 6' & $619.55 \pm 4.53^{\mathrm{abcd}}$ & $460.00 \pm 14.15^{\mathrm{j}}$ & $460.03 \pm 30.03^{\text {bcde }}$ & $1857.65 \pm 73.84^{\mathrm{fg}}$ & $439.51 \pm 10.26^{\mathrm{abc}}$ \\
\hline 'TE 7' & $1033.70 \pm 139.08^{\mathrm{efg}}$ & $324.63 \pm 13.74^{\mathrm{gh}}$ & $515.10 \pm 43.05^{\mathrm{def}}$ & $1964.28 \pm 97.11^{\mathrm{fgh}}$ & $645.75 \pm 92.86^{\mathrm{efgh}}$ \\
\hline 'TE 8' & $929.89 \pm 98.90^{\mathrm{def}}$ & $361.32 \pm 5.71^{\mathrm{hi}}$ & $514.35 \pm 31.54^{\mathrm{def}}$ & $2009.33 \pm 43.55^{\text {fgh }}$ & $571.41 \pm 85.85^{\text {cdefg }}$ \\
\hline 'TE 9' & $1548.77 \pm 57.88^{\mathrm{jkl}}$ & $267.81 \pm 21.53^{\mathrm{f}}$ & $552.64 \pm 63.07^{\mathrm{ef}}$ & $1922.23 \pm 286.58^{\mathrm{fgh}}$ & $533.12 \pm 42.55^{\text {abcdef }}$ \\
\hline 'TE 10' & $1145.59 \pm 34.37^{\text {fghi }}$ & $185.01 \pm 48.29^{\mathrm{a}}$ & $345.15 \pm 14.02^{\mathrm{a}}$ & $1275.98 \pm 174.20^{\mathrm{bc}}$ & $516.60 \pm 65.33^{\text {abcde }}$ \\
\hline 'TS 1 ' & $1883.13 \pm 243.83^{1}$ & $277.90 \pm 21.87^{\mathrm{fg}}$ & $431.25 \pm 31.54^{\mathrm{abcd}}$ & $1876.67 \pm 38.54^{\mathrm{fg}}$ & $503.58 \pm 81.34^{\mathrm{abcde}}$ \\
\hline 'TS 2' & $1696.57 \pm 422.64^{\text {ghijk }}$ & $189.55 \pm 37.05^{\mathrm{ab}}$ & $490.82 \pm 12.26^{\mathrm{cdef}}$ & $1819.61 \pm 121.14^{\mathrm{f}}$ & $544.38 \pm 48.31^{\text {bcdef }}$ \\
\hline 'TS 3' & $1445.03 \pm 160.89^{\mathrm{hijk}}$ & $171.49 \pm 10.12^{\mathrm{abc}}$ & $688.30 \pm 29.78^{\mathrm{hi}}$ & $1797.08 \pm 86.85^{\text {efg }}$ & $765.89 \pm 36.04^{\mathrm{hij}}$ \\
\hline 'TS 4' & $1237.76 \pm 136.07^{\text {fghij }}$ & $235.17 \pm 11.6^{\mathrm{def}}$ & $653.51 \pm 46.30^{\mathrm{gh}}$ & $1797.08 \pm 116.64^{\mathrm{efg}}$ & $698.81 \pm 42.30^{\text {fghi }}$ \\
\hline 'TS 5' & $754.29 \pm 101.82^{\text {bcde }}$ & $205.31 \pm 5.85^{\text {bcde }}$ & $415.73 \pm 10.51^{\mathrm{abc}}$ & $1647.16 \pm 196.23^{\text {cdef }}$ & $381.69 \pm 39.55^{\mathrm{ab}}$ \\
\hline 'TA 1 ' & $787.52 \pm 164.32^{\text {cdef }}$ & $241.19 \pm 16.70^{\mathrm{ef}}$ & $483.06 \pm 21.78^{\text {cdef }}$ & $1117.54 \pm 224.01^{\mathrm{b}}$ & $511.84 \pm 111.88^{\text {abcdef }}$ \\
\hline 'TA 2' & $470.78 \pm 176.44^{\mathrm{a}}$ & $235.85 \pm 12.97^{\text {cdef }}$ & $541.63 \pm 404.72^{\mathrm{ef}}$ & $1910.46 \pm 315.87^{\mathrm{fgh}}$ & $752.37 \pm 131.15^{\mathrm{ghi}}$ \\
\hline 'TA 3' & $889.61 \pm 148.29^{\text {def }}$ & $265.23 \pm 5.59^{\mathrm{f}}$ & $560.40 \pm 287.33^{\mathrm{f}}$ & $1259.96 \pm 192.47^{\mathrm{b}}$ & $459.28 \pm 44.80^{\mathrm{abcd}}$ \\
\hline 'TA 4' & $1312.24 \pm 347.10^{\mathrm{ijk} l}$ & $248.72 \pm 33.89^{\mathrm{def}}$ & $774.40 \pm 178.46^{\mathrm{ij}}$ & $2974.45 \pm 111.63^{h}$ & $1225.92 \pm 95.61^{1}$ \\
\hline 'TA 5', & $645.74 \pm 101.01^{\mathrm{abcd}}$ & $242.69 \pm 23.94^{\mathrm{ef}}$ & $566.91 \pm 193.72^{\mathrm{fg}}$ & $1340.80 \pm 15.52^{\text {bcd }}$ & $482.06 \pm 48.81^{\mathrm{abcde}}$ \\
\hline 'TALB 1' & $448.45 \pm 21.93^{\mathrm{ab}}$ & $186.48 \pm 9.80^{\mathrm{abcd}}$ & $384.95 \pm 4.51^{\mathrm{ab}}$ & $1069.49 \pm 61.07^{\mathrm{b}}$ & $371.18 \pm 9.76^{\mathrm{a}}$ \\
\hline 'TALB 2' & $1129.87 \pm 114.29^{\text {efghi }}$ & $158.49 \pm 27.95^{\mathrm{a}}$ & $480.56 \pm 52.26^{\text {bcdef }}$ & $393.21 \pm 10.26^{\mathrm{a}}$ & $992.65 \pm 78.34^{\mathrm{k}}$ \\
\hline 'TALB 4' & $384.99 \pm 32.96^{\mathrm{ab}}$ & $161.05 \pm 18.18^{\mathrm{abcd}}$ & $579.92 \pm 159.43^{\mathrm{fg}}$ & $2707.14 \pm 115.88^{h}$ & $1595.35 \pm 39.05^{\mathrm{m}}$ \\
\hline 'TALCY 2' & $459.84 \pm 29.11^{\mathrm{abc}}$ & $184.46 \pm 6.49^{\text {abcde }}$ & $655.01 \pm 183.46^{\mathrm{gh}}$ & $1432.66 \pm 108.88^{\text {bcde }}$ & $838.72 \pm 28.28^{\mathrm{ijk}}$ \\
\hline
\end{tabular}

${ }^{a}$ Values (means \pm standard error) followed by the same letter, within the same column, were not significantly different according to Fisher's least significant difference (LSD) procedure at 95\% confidence level $(n=30)$. TE: cultivar EPSO; TS: cultivar Serón; TA: cultivar Aguilas; TALB: cultivar La Alberca; TALCY: cultivar La Alcayna

$801.68 \mathrm{mg}$ Trolox Eq. $100 \mathrm{~g}^{-1} \mathrm{dw}$, followed by the cultivar 'TA4' with a total of $774.4 \mathrm{mg}$ Trolox Eq. $100 \mathrm{~g}^{-1} \mathrm{dw}$, being on the contrary the cultivar 'TE10' the one that presents a low value with a total of
$345.15 \mathrm{mg}$ Trolox Eq. $100 \mathrm{~g}^{-1} \mathrm{dw}$. On the other hand, the antioxidant activity by the FRAP method presented a range between 393.21 and $2974.45 \mathrm{mg}$ Trolox Eq. $100 \mathrm{~g}^{-1} \mathrm{dw}$, in cultivars 'TALB2' and 
'TA4' respectively. The cultivar 'TE5' presented the highest value in DPPH method (1939.25 mg Trolox Eq. $100 \mathrm{~g}^{-1} \mathrm{dw}$ ), followed by the cultivar 'TALB4' (1595.35 mg Trolox Eq. $100 \mathrm{~g}^{-1} \mathrm{dw}$ ). On the contrary, the cultivar 'TALB1' was the one that presented the lowest value, with a total of $371.18 \mathrm{mg}$ Trolox Eq. $100 \mathrm{~g}^{-1} \mathrm{dw}$.

Grimalt et al. (2019) obtained slightly higher results on the content of H-TAA in flower buds and in L-TAA lower than those of the present work. Tesoriere et al (2007) found lower values of H-TAA and L-TAA in flower buds of Italian cultivars. Aliyazicioglu et al. (2013) obtained lower FRAP values in Turkish cultivars. Mansour et al. (2016) also obtained lower ABTS values in Tunisian cultivars. These differences may be because genotypic and environmental differences.

Correlation between traits and principal component analysis

Those traits that measure chlorophylls content have a very close positive correlation among them. Chlorophyll $a$ and total chlorophyll are correlated negatively with total phenols and total flavonols, whereas that chlorophyll $b$ is positively correlated with carotenoids and H-TAA. Carotenoids are positively correlated with total chlorophyll, chlorophyll $b$ and protein, and negatively with total flavonoids and DPPH. Phenols, flavonoids and flavonols have a positive correlation among them. FRAP and total flavonoids are correlated positively, as well as DPPH and ABTS (Fig. 5).

In order to gain a better understanding of the results and trends of the variables studied (13 traits and 24 Capparis cultivars), the main components analysis (PCA) was applied and results are showed in Table 7 and Figs. 6 and 7.

The first three main components accounted for $68.44 \%$ of the total variation for the results obtained in the caper buds, and the $52.01 \%$ of the variability of the data studied were explained by the first two components. PC1 and PC2 from the PCA explained the 31.35 and the $20.66 \%$ of the variability, respectively (Table 7). The 'TE' group (except 'TE10') is mainly defined by the amount of chlorophylls, while the 'TA' and 'TS' groups (except 'TS2'), 'TYALC' and 'TE10' are principally correlated with phenols, flavonols and flavonoids. 'TS2', 'TALB1' and 'TALB2' are defined by the amount of carotenoids, but not 'TALB4'
Table 7 Eigenvectors of each variable in the three first Principal Components obtained with chemical and biochemical parameters

\begin{tabular}{lrrr}
\hline & PC1 & PC2 & \multicolumn{1}{c}{ PC3 } \\
\hline Eigenvalues & 4.08 & 2.69 & 2.14 \\
Cumulative variation (\%) & 31.35 & 52.01 & 68.44 \\
\hline Parameters & Eigenvectors & & \\
\hline Chlorophyll a & 0.90 & 0.26 & 0.13 \\
Chlorophyll b & 0.81 & 0.14 & 0.40 \\
Total chlorophylls & 0.92 & 0.24 & 0.22 \\
Carotenoids & 0.59 & -0.56 & 0.25 \\
Protein & 0.00 & -0.68 & 0.17 \\
Phenols & -0.61 & -0.08 & 0.50 \\
Flavonoids & -0.44 & 0.39 & 0.63 \\
Flavonols & -0.78 & 0.09 & 0.50 \\
H-TAA & 0.26 & 0.07 & 0.78 \\
L-TAA $_{\text {ABTS }}^{+}$ & 0.36 & 0.13 & 0.04 \\
DPPH $^{\bullet}$ & -0.14 & 0.75 & -0.18 \\
FRAP & 0.07 & 0.75 & -0.40 \\
\hline
\end{tabular}

(Figs. 6 and 7). The first component (PC1) was positively related to chlorophylls, H-TAA and L-TAA, and negatively related to total phenols, flavonoids and flavonols. The PC2 was positively correlated with ABTS, FRAP and DPPH, and was negatively correlated with proteins (Fig. 6). PCA clearly distinguishes the 'TE 'except 'TE10' population on the right of Fig. 3 along with TS2, in positive $\mathrm{PC} 1$. The rest of the cultivars are $\mathrm{PC} 1$ negative including 'TE10', but not including 'TALB1' and 'TALB2' (Fig. 7).

ISSR markers and chemical and bioactive compounds comparison

Comparing the PCA obtained with chemical and functional compounds and ISSR results (Figs. 3 and 7, respectively), we shall observe that although the cultivar distribution is not identical, figures were very similar. In both cases, 'TE' cultivars were grouped, with the exception of 'TE10' cultivar. In the PCA obtained with chemical and functional compounds the 'TE10' cultivar was grouped with the rest of the cultivars no with the other 'TE' cultivar. In the same 


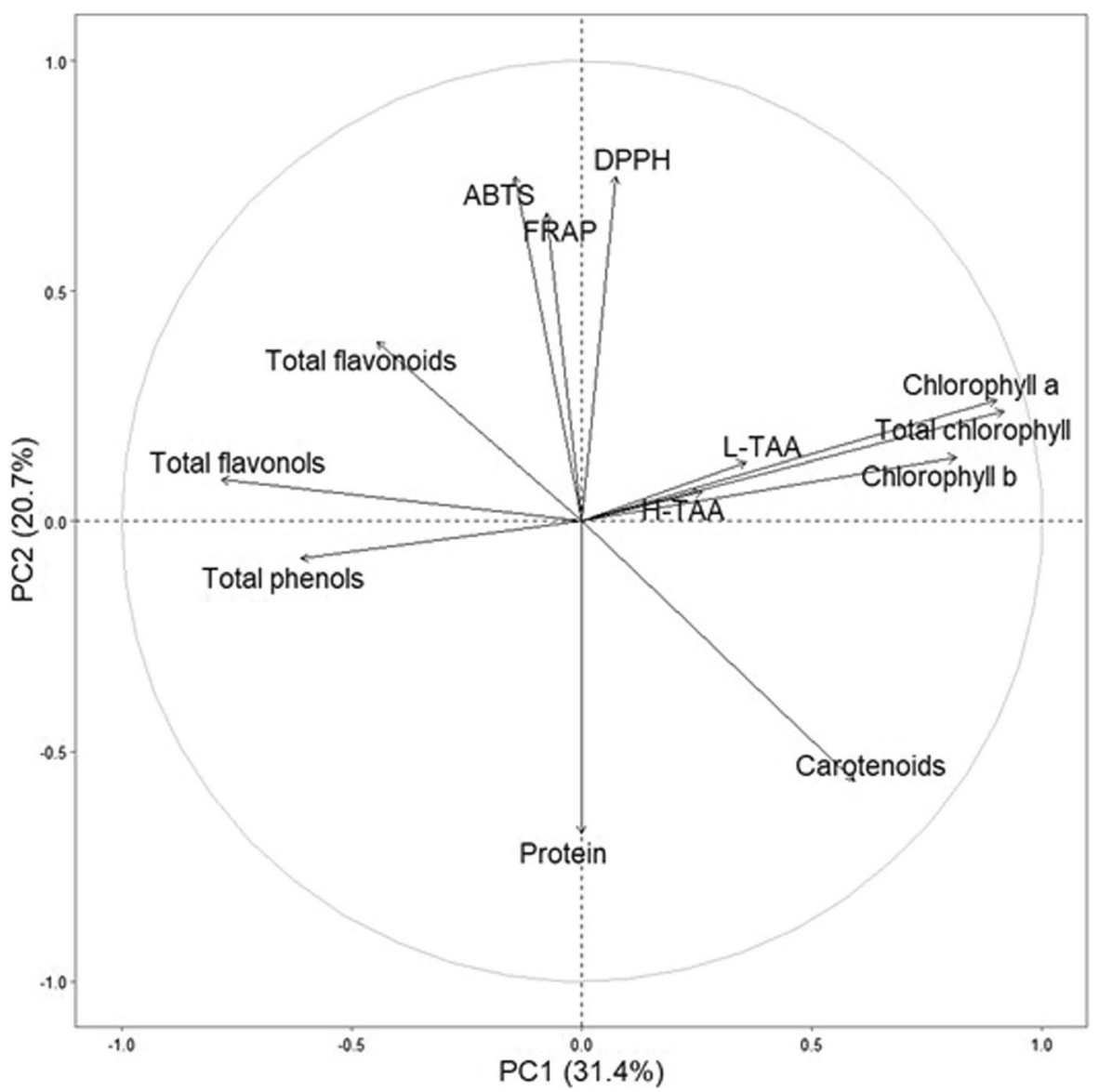

Fig. 6 Variables factor map from principal component analysis using chemical and biochemical parameters

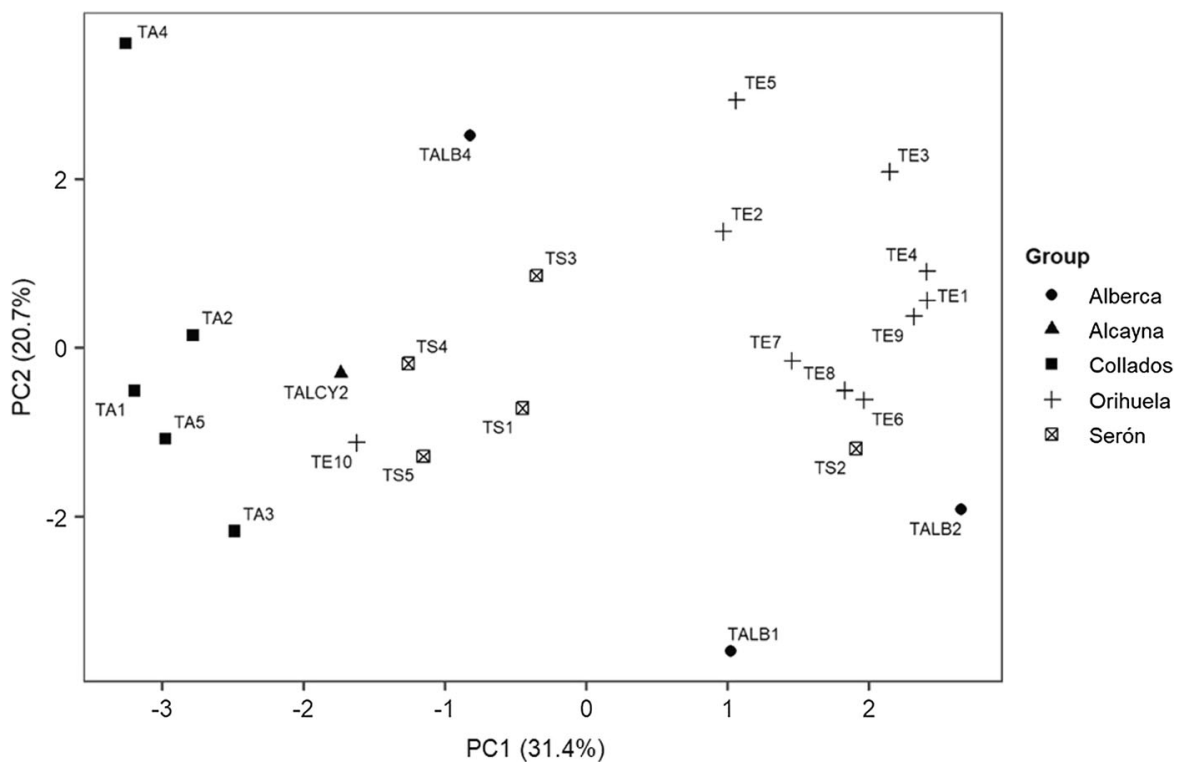

Fig. 7 Principal component analysis using chemical and biochemical parameters 
way, 'TALB1', 'TALB2' and 'TS2' cultivars were grouped with 'TE' cultivars.

\section{Conclusions}

The PCAs carried out seem to indicate that the 'TE' cultivars, except 'TE10', belong to a subspecies, which, since they do not have stipules thorny, must be the rupestris subspecies, while the rest of the populations belong to the spinosa subspecies since they do have stipules thorny. According to the genetic PCA, the cultivar 'TE10' seems to be a hybrid between both subspecies, since it is in an intermediate position, or it belongs to the spinosa subspecies according to the results of the PCA using biochemical parameters.

In any case, from the results of the biochemical and functional parameters studied, it is clear that there is no difference between the spinosa and rupestis subspecies, but rather that in all the parameters studied, except chlorophylls, there is more difference between the results of the subspecies spinosa among them, than with the subspecies rupestris. For all this, for the first time, it can be concluded that the rupestris subspecies that does not present stipules thorny, can be cultivated instead of the spinosa subspecies that does present them, without losing functional or nutritional characteristics of the flower buds, facilitating agronomic work.

Acknowledgements The authors are thankful to the CEBASCSIC Fruit Breeding Group for the DNA quantification assistance.

Author's contribution Conceptualization: P. Legua and F. Hernandez, Methodology: A. Amorós, F. Hernández, M.S. Almansa and S. García-Martínez, Formal analysis and investigation: M. Grimalt, P. Carbonell, Writing-original draft preparation: M. Grimalt and S. García-Martínez; Writing-review and editing: A. Amorós, S. García-Martínez and F. Hernández, Funding acquisition: A. Amorós; Resources: A. Amorós, F. Hernández and S. García-Martínez; Supervision: A. Amorós.

Funding Open Access funding provided thanks to the CRUECSIC agreement with Springer Nature. This work was suported by the Consellería de Educación, Investigación, Cultura y Deportes de la Generalitat Valenciana (AICO-2016/015).

Data availability All data generated or analyzed during this study are included in this published article.

\section{Declarations}

Conflict of interest The authors have no conflicts of interest to declare that are relevant to the content of this article.

Open Access This article is licensed under a Creative Commons Attribution 4.0 International License, which permits use, sharing, adaptation, distribution and reproduction in any medium or format, as long as you give appropriate credit to the original author(s) and the source, provide a link to the Creative Commons licence, and indicate if changes were made. The images or other third party material in this article are included in the article's Creative Commons licence, unless indicated otherwise in a credit line to the material. If material is not included in the article's Creative Commons licence and your intended use is not permitted by statutory regulation or exceeds the permitted use, you will need to obtain permission directly from the copyright holder. To view a copy of this licence, visit http://creativecommons.org/licenses/by/4.0/.

\section{References}

Adams D, Kim J, Jensen R, Marcus L, Slice DE, Walker J (1998) NTSYSpc. Version 2.02c. Applied Biostatistic Inc.

Aichi-Yousfi H, Bahri BA, Medini M, Rouz S, Rejeb MN, Ghrabi-Gammar Z (2016) Genetic diversity and population structure of six species of Capparis in Tunisia using AFLP markers. C R Biol 339:442-453. https://doi.org/10.1016/j. crvi.2016.09.001

Aliyazicioglu R, Eyupoglu OE, Sahin H, Yildiz O, Baltas N (2013) Phenolic components, antioxidant activity, and mineral analysis of Capparis spinosa $\mathrm{L}$. Afr J Biotechnol 12:6643-6649. https://doi.org/10.5897/AJB2013.13241

Al-Safadi B, Faouri H, Elias R (2014) Genetic diversity of some Capparis L. species growing in Syria. Braz Arch Biol Technol 57(6):916-926. https://doi.org/10.1590/S15168913201402549

Ahmadi M, Saeidi H, Mirtadzadini M (2020) Species delimitation in Capparis spinosa group (Capparaceae) in Iran: multivariate morphometric analysis and ISSR markers. Phytotaxa 456:1. https://doi.org/10.11646/phytotaxa.456. 1.1

Anwar F, Muhammad G, Hussain MA, Zengin G, Alkharfy KM, Ashraf M, Gilani A (2016) Capparis spinosa L.: a plant with high potential for development of functional foods and nutraceuticals/pharmaceuticals. Int $\mathrm{J}$ Pharmacol 12:201-2019. https://doi.org/10.3923/ijp.2016.201.219

AOAC (1990) Chlorophyll in plants. In: Helrich KC (ed) Official methods of analysis of the AOAC. AOAC. Arlington. VA, pp 62-63

Argentieri M, Macchia F, Papadia P, Fanizzi FP, Avato P (2012) Bioactive compounds from Capparis spinosa subsp. rupestris. Ind Crops Prod 36:65-69. https://doi.org/10.1016/ j.indcrop.2011.08.007

Arnao MB, Cano A, Acosta M (2001) The hydrophilic and lipophilic contribution to total antioxidant activity. Food Chem 73:239-244. https://doi.org/10.1016/S03088146(00)00324-1 
Benzie IFF, Strain JJ (1996) The ferric reducing ability of plasma (FRAP) as a measure of "antioxidant power": the FRAP assay. Anal Biochem 239:70-76. https://doi.org/10. 1006/abio.1996.0292

Bradford MM (1976) A rapid and sensitive method for the quantitation of microgram quantities of protein utilizing the principle of protein-dye binding. Anal Biochem 72:248-254

Brand-Williams W, Cuvelier ME, Berset C (1995) Use of a free radical method to evaluate antioxidant activity. LWT-Food Sci Technol 28:25-30. https://doi.org/10.1006/abio.1976. 9999

Chang C, Yang M, Wen H, Chern J (2002) Estimation of total flavonoid content in propolis by two complementary colorimetric methods. J Food Drug Anal 10:178-182. https:// doi.org/10.12691/jnh-5-2-4

Doyle JJ, Doyle JL (1990) Isolation of plant DNA from fresh tissue. Focus 12:13-15. https://doi.org/10.4236/ijoc.2019. 92009

Earl DA, Vonholdt BM (2012) Structure harvester: a website and program for visualizing structure output and implementing the Evanno method. Conserv Genet Resour 4:359-361. https://doi.org/10.1007/s12686-011-9548-7

Evanno G, Regnaut S, Goudet J (2005) Detecting the number of clusters of individuals using the software structure: a simulation study. Mol Ecol 14:2611-2620. https://doi.org/ 10.1111/j.1365-294X.2005.02553.x

Fici S (2014) A taxonomic revision of the Capparis spinosa group (Capparaceae) from the Mediterranean to Central Asia. Phytotaxa 174(1):001-024. https://doi.org/10.11646/ phytotaxa.174.1.1

García-Rollán M (1981) Claves de la flora de España (Península y Baleares) (vol 1), pteridofitas, gimnospermas, dicotiledóneas (AJ). Madrid, Spain: Ediciones Mundi-Prensa

Grimalt M, Hernández F, Legua P, Almansa MS, Amorós A (2018) Physicochemical composition and antioxidant activity of three Spanish caper (Capparis spinosa L.) fruit cultivars in three stages of development. Sci Hort 240:509-515. https://doi.org/10.1016/j.scienta.2018.06. 061

Grimalt M, Legua P, Hernández F, Amorós A, Almansa MS (2019) Antioxidant activity and bioactive compounds contents in different stages of flower bud development from three spanish caper (Capparis spinosa) cultivars. Horticult J 88(3):410-419. https://doi.org/10.2503/hortj. UTD-060

Gristina AS, Fici S, Siragusa M, Fontana I, Garfi G, Carimi F (2014) Hybridization in Capparis spinosa L.: molecular and morphological evidence from a Mediteranean island complex. Flora 209:733-741. https://doi.org/10.1016/j. flora.2014.09.002

Gull T, Anwar F, Sultana B, Cervantes MA, Nouman W (2015) Capparis species: a potential source of bioactives and highvalue components: a review. Ind Crops Prod 67:81-96. https://doi.org/10.1016/j.indcrop.2014.12.059

Inocencio C, Cowan RS, Alcaraz F, Rivera D, Fay MF (2005) AFLP fingerprinting in Capparis subgenus Capparis related to the commercial sources of capers. Genet Resour Crop Evol 52:137-144

Inocencio C, Rivera D, Alcaraz F, Tomás-Barberán FA (2000) Flavonoid content of commercial capers (Capparis spinosa, C. sicula and C. orientalis) produced in Mediterranean countries. Eur Food Res and Technol 212:70-74

Inocencio C, Rivera D, Obón MC, Alcaraz F, Barrena JA (2006) A systematic revision of Capparis section Capparis (Capparaceae). Ann Mo Bot Gard 93:122-149

Jakobsson M, Rosenberg NA (2007) CLUMPP: a cluster match.ing and permutation program for dealing with labels witching and multimodality in analysis of population structure. Bioinformatics 23:1801-1806. https://doi.org/ 10.1093/bioinformatics/btm233

Kumaran SP, Kutty BC, Chatterji A, Subrayan PP, Mishra KP (2007) Radioprotection against DNA damage by an extract of Indian green mussel Perna viridis (L.). J Environ Pathol Toxicol Oncol 26:263-272. https://doi.org/10.1615/ jenvironpatholtoxicoloncol.v26.i4.30

Lê S, Josse J, Husson F (2008) FactoMineR: an R package for multivariate analysis. J Stat Softw 25(1):1-18. https://doi. org/10.18637/jss.v025.i01

Liu C, Xue GP, Cheng B, Wang X, He J, Liu GH, Yang WJ (2015) Genetic diversity analisys of Capparis spinosa L. population by using ISSR markers. Genet Mol Res 14(4):16476-16483. https://doi.org/10.4238/2015. December.9.19

Maldini M, Foddai M, Natella F, Addis R, Chessa M, Petretto GL, Tuberoso CIG, Pintore G (2016) Metabolomic study of wild and cultivated caper (Capparis spinosa L.) from different areas of Sardinia and their comparative evaluation. J Mass Spectrom 51:716-728. https://doi.org/10.1002/jms. 3830

Mansour RB, Jilani IBH, Bouaziz M, Gargouri B, Elloumi N, Attia H, Ghrabi-Gammar Z, Lassoued S (2016) Phenolic contents and antioxidant activity of ethanolic extrac of Capparis spinosa. Cytotechnology 68:135-142. https:// doi.org/10.1007/s10616-014-9764-6

Mateo G, Crespo MB (1995) Flora abreviada de la Comunidad Valenciana. GAMMA ed. Alicante. Spain

Nei M, Li WH (1979) Mathematical model for studying genetic variation in terms of restriction endonucleases. Proc Natl Acad Sci USA 76:5269-5273

Özbek Ö, Kara A (2013) Genetic variation in natural populations of Capparis from Turkey, as revealed by RAPD analysis. Plant Syst Evol 299:1911-1933. https://doi.org/ 10.1007/s00606-013-0848-0

Özcan M, Akgül A (1998) Influence of species harvest date and size on composition of capers (Capparis spp.) flower buds. Nahrung 42:102-105. https://doi.org/10.1002/(SICI)15213803(199804)42:02\%3c102::AID-FOOD102\%3e3.0. $\mathrm{CO} ; 2-\mathrm{V}$

Peakall R, Smouse PE (2012) GenAlEx 6.5: genetic analysis in Excel. Population genetic software for teaching andre search—an update. Bioinformatics 28:2537-2539. https:// doi.org/10.1093/bioinformatics/bts460

Powell W, Morgante M, Andre C, Hanafey M, Vogel J, Tingey S, Rafalski A (1996) Comparison of RFLP, RAPD, AFLP and SSR markers for germoplasm improvement. Mol Breed 3:225-238. https://doi.org/10.1007/BF00564200

Pritchard JK, Stephens M, Donnelly P (2000) Inference of population structure using multi locus genotype data. Genetics 155:945-959 (PMID: 10835412)

Re R, Pellegrini N, Proteggente A, Pannala A, Yang M, RiceEvans C (1999) Antioxidant activity applying an improved 
ABTS radical cation decolorization assay. Free Radic Biol Med 26:1231-1237. https://doi.org/10.1016/s08915849(98)00315-3

Reche J, García-Martínez S, Carbonell P, Almansa MS, Hernández F, Legua P, Amorós A (2019) Relationships between physico-chemical and functional parameters and genetic analysis with ISSR markers in Spanish jujubes (Ziziphus jujuba Mill.) cultivars. Sci Hort 253:390-398. https://doi.org/10.1016/j.scienta.2019.04.068

Rhimi A, Mnasri S, Ben Ayed R, Bel Hajj Ali I, Hjaoujia S, Boussaid M (2019) Genetic relationships among subspecies of Capparis spinosa L. from Tunisia by using ISSR markers. Mol Biol Rep 46:2209-2219. https://doi.org/10. 1007/s11033-019-04676-z

Saifi N, Ibijbijen J, Echchgadda G (2011) Genetic diversity of caper plant (Capparis ssp.) from North Morocco. J Food Agric Environ 9:299-304. https://doi.org/10.13140/RG.2. 1.4013.0081

Singleton VL, Orthofer R, Lamuela-Raventos RM (1999) Analysis of total phenols and other oxidation substrates and antioxidants by means of Folin-Ciocalteu reagent. Methods Enzymol 299:152-178. https://doi.org/10.1016/S00766879(99)99017-1

Tamboli AS, Yadav PB, Gothe AA, Yadav SR, Govindwar SP (2018) Molecular phylogeny and genetic diversity of genus Capparis (Capparaceae) based on plastid DNA sequences and ISSR markers. Plant Syst Evol 304:205-217. https:// doi.org/10.1007/s00606-017-1466-z

Tesoriere L, Butera D, GentileLivrea CA (2007) Bioactive components of caper (Capparis spinosa L.) from Sicily and antioxidant effects in a Red meat simulated gastric digestion. J Agric Food Chem 55:8465-8471. https://doi.org/10. 1021/jf0714113

Tlili N, Khaldi A, Triki S, Munne-Bosch S (2010) Phenolic compounds and vitamin antioxidant of caper (Capparis spinosa). Plant Foods Hum Nutr 65:260-265. https://doi. org/10.1007/s11130-010-0180-6

Tlili N, Nasri N, Saadaoui E, Khaldi A, Triki S (2009) Carotenoid and tocopherol composition of leaves, buds, and flowers of Capparis spinosa grown wild in Tunisia. J Agric Food Chem 57:5381-5385. https://doi.org/10.1021/ jf900457p
Ulukapi K, Özdemir B, Kulcan A, Tetik N, Ertekin C, Onus AN (2016) Evaluation of biochemical and dimensional properties of naturally grown Capparis spinosa var. Spinosa and Capparis ovata var. Palaestina. IJAIR 5:195-200

Valero D, Díaz-Mula HM, Zapata PJ, Castillo S, Guillén F, Martínez-Romero D, Serrano M (2011) Postharvest treatments with salicylic acid, acetylsalicylic acid or oxalic acid delayed ripening and enhanced bioactive compounds and antioxidant capacity in sweet cherry. J Agric Food Chem 59:5483-5489. https://doi.org/10.1021/jf200873j

Wang Q, Zhang M, Yin L (2016) Genetic diversity and population differentiation of Capparis spinosa (Capparaceae) in Northwestern China. Biochem Syst Ecol 66:1-7. https:// doi.org/10.1007/s12298-018-0518-3

Wojdyło A, Nowicka P, Grimalt M, Legua P, Almansa MS, Amorós A, Carbonell-Barrachina AA, Hernández F (2019) Polyphenol compounds and biological activity of caper (Capparis spinosa L.) flowers buds. Plants 8:539. https:// doi.org/10.3390/plants8120539

Wickham H (2007) Clusterfly: explore clustering interactively using $\mathrm{R}$ and GGobi. http://had.co.nz/clusterfly. R package version 0.2.3.

Wu Z, Gu L, Holden J, Haytowitz DB, Gebhardt SW, Beecher G, Prior RL (2004) Development of database for total antioxidant capacity in foods: a preliminary study. J Food Comp Anal 17:407-422. https://doi.org/10.1016/j.jfca. 2004.03.001

Yap V, Nelson RJ 1996 WinBoot: A program for performing bootstrap analysis of binary data to determine the confidence limits of UPGMA-based dendrograms. International Rice Research Institute, Manila, Philippines [online]. Available from http://irri.org/science/software/winboot. asp

Zohary M (1960) The species of Capparis in the Mediterranean and the Near Eastern countries. Bull Res Counc Isr 8:49-64

Publisher's Note Springer Nature remains neutral with regard to jurisdictional claims in published maps and institutional affiliations. 